Article

\title{
Drivers of Sustainable Apparel Purchase Intention: An Empirical Study of Malaysian Millennial Consumers
}

\author{
Nornajihah Nadia Hasbullah ${ }^{1}\left(\mathbb{D}\right.$, Zuraidah Sulaiman ${ }^{2, *(\mathbb{D})}$, Adaviah Mas'od ${ }^{2}$ (D) \\ and Hanis Syuhada Ahmad Sugiran ${ }^{2} \mathbb{D}$ \\ 1 Faculty of Business and Management, Universiti Teknologi Mara (UiTM), Cawangan Melaka \\ Kampus Bandaraya Melaka, Melaka 75350, Malaysia; najihahnadia@uitm.edu.my \\ 2 Azman Hashim International Business School, Universiti Teknologi Malaysia, Skudai 81310, Malaysia; \\ adaviah@utm.my (A.M.); hnissyuhada@gmail.com (H.S.A.S.) \\ * Correspondence: zuraidahs@utm.my
}

Citation: Hasbullah, N.N.;

Sulaiman, Z.; Mas'od, A.; Ahmad Sugiran, H.S. Drivers of Sustainable Apparel Purchase Intention: An Empirical Study of Malaysian Millennial Consumers. Sustainability 2022, 14, 1945

https://doi.org/10.3390/su14041945

Academic Editors: Jihyun Kim-Vick and Flavio Boccia

Received: 27 October 2021

Accepted: 13 January 2022

Published: 9 February 2022

Publisher's Note: MDPI stays neutral with regard to jurisdictional claims in published maps and institutional affiliations.

Copyright: (C) 2022 by the authors. Licensee MDPI, Basel, Switzerland. This article is an open access article distributed under the terms and conditions of the Creative Commons Attribution (CC BY) license (https:// creativecommons.org/licenses/by/ $4.0 /)$.

\begin{abstract}
The fashion industry has expanded at the expense of the environment. Consumption and environmental pollution both serve as a wake-up call to the global endeavour to adopt more socially and environmentally responsible behaviours. It implies, in particular, a paradigm shift in consumer behaviour away from conventional to green products. Understanding the factors that influence consumer purchasing decisions is critical in developing the demand for and commitment to sustainable apparel consumption. In support of the United Nation's efforts to promote sustainable consumption in Malaysia, a study was conducted to determine the motivating factors that influence consumers' purchase intentions for sustainable apparel. The moderating effect of fashion consciousness on the outcome was also examined. An extended model of the Motivation-Opportunity-Ability (MOA) Theory and Self-Determination Theory (SDT) was developed and tested using 324 responses collected from the Malaysian millennial generation in six major urban locations. The results of the structural equation modelling analysis indicated that the elements of motivation, opportunity, and ability were all positively linked with the sustainable apparel purchase intention. Fashion consciousness had a moderating effect on the relationships between the three drivers (motivation, opportunity, and ability) and purchase intention. The research findings provide valuable insights for businesses to formulate a sustainable and unified business model that incorporates environmental, social, and consumer considerations into core business practices. These insights would also help designers to advance the development of sustainable products as an area of innovation and support policymakers in achieving the UN's 17 Sustainable Development Goals (SDGs).
\end{abstract}

Keywords: purchase intention; sustainable apparel; motivation drivers; self-determination theory; motivation-opportunity-ability theory; Malaysian consumers

\section{Introduction}

The prosperity of the apparel and textile industries was controversially built upon the sacrifices of safety and the long-term health of the environment. The substantial amounts of resources consumed in the production and manufacturing of apparel have had devastating impacts on the environment, such as river pollution, toxic chemical releases, excessive waste generation, and greenhouse gas emissions, all of which have exacerbated the problem of environmental degradation. Indeed, the textile industry was ranked among the world's highest polluters of fresh air [1-3]. With mounting pressure and a worldwide focus on socially responsible behaviour, sustainability is no longer an option but a key priority and a central strategy. Besides, it is no longer an issue limited to large corporations; it now affects all stakeholders, both individually and collectively [4]. Recent research indicates that shifts away from conventional products to sustainable consumption have emerged in tandem with the growing public concern about climate change [5-7]. In this regard, 
consumers who perceive an organisation as sustainable are optimistic about it and want to reciprocate positively [8]. The time has come for the industry to commit to sustainability targets while promoting sustainability comprehensively, from raw material processing to clothing finishing [9-12].

Responsible consumption and production through efficient resource management and better consumption patterns have been part of the Sustainable Development Goals (SDGs). Given the scope of the textile industry and clothes being one of the universal necessities for living, the industry has a large opportunity to rise and become a pioneer in preserving the environment. To ensure the success of this strategic shift, wide acceptance and solid support from consumers are crucial. A sustainable business plan in the fashion industry not only involves the implementation of strategies designed for the theme of sustainability, but also the development of new business models that fundamentally recognise consumer engagement to drive more eco-friendly consumption and habits [13]. Therefore, incorporating the SDGs and fostering consumer confidence into the industry are both interrelated and extremely important.

Sustainable consumption has spread beyond the Western markets to include Asian, Latin American, and Eastern European markets [14]. Although Malaysia experiences slow progress in the sustainable fashion trend, several viable initiatives have been proposed over the last few years. Some of the notable movements include the 17 th United Nations Development Programme Plan, Shared Prosperity Vision 2030, sustainability campaigns of Malaysia External Trade Development Corporation (MATRADE, Kuala Lumpur, Malaysia), joint initiatives of non-governmental organisations such as Fashion Revolution, World Wide Fund (WWF), the Council of ASEAN Fashion Designers (CAFD), as well as the collaborations of fashion entrepreneurs. In particular, the Malaysian government has expressed unwavering support for international green product standards. In 2015, along with 193 United Nations member states, Malaysia joined the global alliance for sustainable, resilient, and inclusive development by committing itself to the 17 Sustainable Development Goals (SDGs). The SDGs, at their core, serve as a blueprint for countries seeking to ensure a more sustainable future for their nation and people.

Souri et al. [15] emphasised the importance of conducting additional studies to elucidate issues. According to the literature, the majority of past research on sustainable fashion has been conducted in Western countries, with little attention paid to non-Western countries. It was understood that the level of sustainable concern might differ according to the country's development status and cultural differences. On a similar line, the motivation to spend on sustainable products such as organic food and cosmetics differs slightly from the motivation to consume sustainable garments, as clothing influences the development of appearance, self-confidence, style, and image. All product categories should not be treated the same way, as this will result in people expressing their concern for the environment without taking action.

Given the paucity of research on sustainable garment purchasing in non-Western contexts, a knowledge gap exists about the factors influencing customers' purchase intentions in developing nations. As such, this article examined Malaysian consumers' motivations for sustainable consumption and the psychological influence of these internal drives on buying decisions. Using the Motivation-Opportunity-Ability (MOA) framework and SelfDetermination Theory (SDT), the researchers developed an extended model to investigate the effect of motivational values, opportunity, and ability on consumers' purchase intention. The study also examined the moderating effect of fashion consciousness on the outcome. This empirical study would lay the groundwork for practitioners and policymakers to develop successful, long-term sustainability programmes and policies, thereby reaching long-term sustainability targets in the garment industry.

The following is the structure of this paper: a literature review justifying the hypotheses, the research method, results, and discussion prior to reaching the conclusions. 


\section{Literature Review}

\subsection{Sustainable Fashion}

Sustainable fashion is a growing concept that combines sustainable development and fashion, but it has no universally acknowledged definition. The concept encompasses all aspects of fashion and is used to refer to the slow fashion movement, eco-green or organic fashion, ethical fashion, and recycled fashion [16,17]. Henninger et al. [18] attempted to clarify the concept by categorising sustainable fashion into vintage, vegan, artisan, second-hand, locally manufactured, custom-made, and fair-trade certified products. These categories suggest fashion's originality and rarity, which are commonly associated with luxury brands. Besides purchasing actual sustainable fashion, consciously prolonging the life of one's clothing while reducing clothing purchases is also considered a sustainable practice [16]. Nevertheless, a definition of sustainable fashion will be incomplete unless it considers both environmental and socio-economic factors. Some scholars acknowledge that luxury fashion and sustainable fashion share characteristics such as durability and rarity in terms of the environmental dimension $[19,20]$. Thus, the perspective of luxury fashion has been assimilated into the context of sustainable fashion after weighing the compatibility of their natures and attributes. In this study, sustainable fashion refers to sustainable apparel, which includes tops, pants, blouses, jackets, underwear, and other types of clothing.

\section{Movement of Sustainable Fashion in Malaysia}

Emerging countries can be described as those nations that are striving to become developed countries and are generally in line with an economically disciplined track. Likewise, emerging countries have become significant change agents in the consumer market, especially in helping to address and safeguard the environment by producing and selling green products [21]. Specifically, the sustainable fashion scene in Malaysia is slow but promising [22]. This has been demonstrated by the growing number of sustainable fashion entrepreneurs that conjoin with the objectives carried out by government organisations. It can be seen that when the Malaysia External Trade Development Corporation (MATRADE), through its press release (Malaysia External Trade Development Corporation, 2017) [23], focuses more on promoting Malaysian companies to be involved in the sustainability initiatives. Moreover, the clothing industry also fights for and applies sustainability values, as demonstrated by several fashion companies such as Real-M, KANOE, Zibossa, and Nukleus Wear. Simultaneously, non-profit organisations around the world, through their fashion revolution campaigns, have begun to advocate for sustainable, ethical, and fair fashion. The Fashion Revolution has spread to over 100 countries around the world, including Malaysia [24].

\subsection{Motivation-Opportunity-Ability (MOA) Model and Mini Theories of Self-Determination Theory (SDT), Organismic Integration Theory (OIT)}

Customers make their purchasing decisions based on their perceptions of an organization's social and environmental commitments as well as their evaluation of a product or service [25]. Numerous theories, such as the Theory of Planned Behavior (TPB) and the Theory of Reasoned Action (TRA), have included perceptions as factors affecting purchasing intentions, but they hardly explain the motivation for purchasing decisions. Meanwhile, previous studies have utilised the MOA model to investigate how people evaluate various types of information, such as advertising, marketing performance, or brand recognition [26-28]. However, the model overlooks the antecedents of overall motivation. The motivational component of the model merely focuses on an individual-oriented strategy and ignores emerging ties with other people. This study introduced another subset component of motivation to overcome the existing constraint in the model, while the current subset can be reassigned to other factors.

To enhance the case for circumventing MOA limitation, this study adds a sub-theory of Self-Determination Theory (SDT): Deci and Ryan's (1985) Organismic Integration Theory (OIT). OIT offers a more comprehensive account of motivation by including the internal- 
isation of external influences and their transformation into motivators or demotivators. According to the theory, there are different levels of motivation (automotive, extrinsic, and intrinsic). The extrinsic motivation has external, introjected, identified, and integrated regulatory styles, and the intrinsic motivation has intrinsic regulation [27]. OIT continues to make progress along this continuum of motivation types towards the internalisation of higher-level motivation states.

\subsubsection{Motivation}

Motivation incorporates readiness, willingness, interest, and a desire to engage in a determined behaviour [26]. Both intrinsic motivation and external regulation factors are viewed as important drivers in fostering individual autonomy, enhancing their self-esteem, and improving general well-being [28].

Numerous empirical studies examined consumer motivation and the behavioural intention towards the sustainability of luxury fashion [29-35]. In the early studies of purchase motivations, consumer motives for luxury consumption have been classified as intrinsic and extrinsic orientations. The intrinsic orientation satisfied purchase through internal self-fulfilment goals, while the extrinsic orientation satisfied purchase through a reflection on others' perceptions [29]. Extrinsic motivation is commonly associated with the theory of conspicuous consumption, which alludes to customers purchasing luxury goods as a symbol of wealth and status. Ki and Kim [33] asserted that both intrinsic and extrinsic motivation play a critical role in and contribute to the purchase intentions of sustainable fashion. In this regard, intrinsic motivation influences purchase intention through the environmental elements, personal style, and social consciousness, whereas extrinsic motivation accomplishes the goal through status consciousness, public self-consciousness, and the pursuit of the latest fashion.

Consumer motivation for luxury brands has been growing. According to [33], the most important factor leading to the extrinsic motivation for consumers who have a penchant for luxury brands is their appealing appearance. Luxury brands engage consumers in the identification process while also creating an unspoken meaning that has an influence on the development of an individual self-concept. If the brand accurately depicts the consumer's social style, the collection will be included, and the purchase would be performed. Meanwhile, Truong [36] discovered that intrinsic motivation was also positively associated with the consumption of luxury goods for inconspicuous reasons such as self-directed enjoyment and perceived product quality. This inconspicuous consumption is a growing trend that represents a shift in customer attitudes toward luxury brands. Rather than being associated with social class and rank, luxury good consumption has evolved into a highly personalised experience [37]. Nwankwo [32] reported that the purchase of luxury products has increased in popularity among wealthier and more educated consumers in recent years due to their demand for quality, originality, and exclusivity. In other words, inconspicuous consumption appeared to be more appealing to intrinsically motivated consumers with high needs for distinctiveness. However, Shao et al. [34] asserted that consumers responded favourably to luxury consumption when luxury products were subtly promoted rather than explicitly promoted.

Simultaneously, fast fashion buyers are increasingly avoiding non-sustainable products in favour of sustainable ones [38]. Gazzola et al. [39] documented a growing consensus among the younger generation to place a higher premium on environmental sustainability, hence disfavouring non-sustainable apparel consumption. From the perspective of business practitioners, consumers' increased sensitivity and positive attitudes towards sustainability are essential for enabling a shift in business focus towards sustainability while providing more product options to satisfy consumers' preferences and their eco-friendly values. Integrating social responsibility into the value proposition could provide a new source of competitive advantage in the fashion market and enhance the overall reputation of the fashion industry. 
With a particular focus on sustainable fashion in other countries, some researchers have examined the significance of personal motivations in the purchase of sustainable clothing. They assert that this behaviour is the result of an individual cost-benefit analysis $[8,12,26]$ which includes positive beliefs about sustainable apparel, a sense of social approval for the purchase of sustainable clothing, and a sense of control over this behaviour. An Indonesian study [30] revealed that social norms and attitudes influenced the purchase of sustainable fashion products. Similarly, Malaysians' sustainable consumption is also motivated by the psychological need for connectedness. Consumers perceive their sustainable consumption practises as a means of meaningfully caring for and connecting with other members of their community. Consumers who satisfy their need to communicate with others may experience an elevated sense of well-being in the form of personal growth and self-improvement that coincides with external motivation. The effects of social norms appear to be highly context-dependent [38].

Drawing from the findings of previous research, this study infers that motivation positively affects consumers' purchase intentions for sustainable apparel. Thus, the following hypothesis is formulated:

Hypothesis $\mathbf{1}$ (H1). There is a positive relationship between motivation and sustainable apparel purchase intention.

\subsubsection{Opportunity}

Opportunity refers to the circumstances that allow or facilitate a person to perform a behaviour. It reflects the degree to which a situation is conducive to achieving the desired outcome. Several situational factors, such as time availability, cost, attention paid, amount of distractions, or repetitions, can all either contribute or impede the desired outcome. Numerous studies have been conducted to examine the opportunity for sustainable fashion, focusing on sustainability and green marketing themes. According to SDT, opportunity can be explained by evaluating the restrictions on consumers' decision-making processes regarding environmental behaviour. Gazzola et al. [39] and Bos et al. [40] highlighted that opportunity could be translated into availability, which denotes convenience and barriers to acquiring sustainable products. Major barriers that stop consumers from purchasing green products include structural conditions that impede sustainable behaviours and deeply embedded social and cultural norms that implicitly dictate behaviour [41]. For example, a study by Wang et al. [42] indicated that most Chinese consumers implicitly perceive luxury brands with a mission of exemplarity and a duty to be socially and environmentally sustainable based on their price and promised superior quality. This reassures the belief that consumers are more likely to adopt sustainable consumption practices when the product offerings are customised to maximise consumers' utilities [43].

Previous studies have identified a number of variables that influence consumers' perceived opportunity for sustainable consumption. Despite the awareness of environmental concerns, consumers tend to focus on price, value, and style in the decision to purchase sustainable clothes [44,45]. Limited retail stores, green alternatives, style, and size options often make purchasing the sustainable apparel challenging for consumers [46]. Accessibility and affordability were also young consumers' utility evaluations of purchasing sustainable clothes [47]. Indeed, sustainable, or ethical, clothing is more expensive than trendy clothing. As a result, low-income shoppers are deterred from purchasing the products. Price turned out to be a key determinant not only for the purchase of eco-friendly commodities but also for bio-based products [48]. Besides, some consumers resisted the idea of sustainable or green products largely because of inadequate alternatives to meet their needs and expectations [49].

To achieve favourable market appraisal, fashion merchandisers and designers should explore the potential of market demand and design environmentally friendly apparel that meet consumers' aspirations [42]. Aside from the quality requirements, eco-conscious 
designs and eco-friendly strategies are vital to maintaining momentum on the development of sustainable clothing. Thus, the following is hypothesised:

Hypothesis 2 (H2). There is a positive relationship between opportunity and sustainable apparel purchase intention.

\subsubsection{Ability}

Ability refers to an individual's capacity to act. Even the most driven individual is unlikely to engage in the designated behaviour without the appropriate abilities. Individual consumers have varying levels of ability and may face a variety of financial and knowledgebased constraints when making green purchases [50].

Numerous researchers have investigated ability via the lens of product experience, consumer knowledge, environmental knowledge, product knowledge, and perceived consumer effectiveness [51-53]. According to Paco and Gouveia's [52] research findings, despite the rise in environmental knowledge and heightened awareness of environmental issues, the perception of individual responsibility for environmental protection remained low. McNeill and Moore [51] asserted that a persistent threat to sustainable consumption was a lack of understanding of sustainable or ethical fashion production. Without a doubt, a lack of knowledge on the part of customers can function as a barrier to fostering a positive attitude toward sustainable fashion consumption [51].

Recent research by Sandra and Alessandro [48] revealed that a large percentage of consumers were driven to sustainable products primarily to mitigate negative impacts on human health and, secondarily, on the environment. It demonstrated a greater willingness on the part of the public to put their knowledge of sustainable consumption into action and so avert aggravation of present problems. This is consistent with Munerah et al.'s [54] findings in their sustainability study. The more knowledgeable an individual is about the environmental damage caused by non-sustainable products, the more favourable the proposition for purchasing sustainable products becomes. Similarly, Bong Ko and Jin [53] demonstrated that environmental knowledge could significantly influence consumers ${ }^{\prime}$ behavioural intentions while simultaneously enhancing their level of perceived control and attitudes towards sustainable fashion consumption.

The literature documents the extent to which consumers comprehend social and environmental issues, as well as how this information shapes consumers' knowledge and abilities to engage in sustainable consumption. The reviews confirm that environmental knowledge positively influences consumers' green purchase intentions and behaviour. Thus, the following hypothesis is proposed:

Hypothesis 3 (H3). There is a positive relationship between ability and sustainable apparel purchase intention.

\subsection{Fashion Consciousness}

Fashion is classified as a high-involvement product. Fashion consciousness is a useful consumer trait for apparel marketers since it measures a person's involvement with fashion styles or clothing. The majority of fashion consciousness research is targeted at young consumers, such as students. Young consumers have various motivations and perspectives when it comes to clothing consumption. Their fashion choices are more complicated as a result of their great exposure to a variety of fashion ideas, ranging from minimalism to opulence, eco-fashion to smart-fashion, or self-concept to social conformity [47]. Young fashion consumers are more conscious of the environmental impacts of fashion. They expressed strong concerns for environmental sustainability, prompting a call for clothing minimalism by reducing, reusing, and recycling apparel [47]. In this sense, this consumer group is highly involved in fashion, as clothing is an integral part of their lives and identities [55].

Consumer involvement in fashion indicates their preferences in fashion orientation, in addition to highlighting one's interest in physical appearance [56]. Aside from prioritising 
eco-friendly fabric or textile material, sustainable fashion should be market-sensitive by conforming to the trending styles and designs [57,58]. Wagner et al. [59] posited that environmentally friendly fashion products have great potential to exemplify a distinctive style in terms of product appearance. Besides, sustainable fashion provides a vast frontier for the fashion industry to experiment with new designs or innovations by harnessing the power of creativity while simultaneously expanding the options available to fashionconscious consumers. In this aspect, the industry has a promising outlook, with significant innovation opportunities and a commitment to environmental sustainability [60].

Fashion consciousness was generally used to assess an individual's beliefs and attitudes towards fashion, thereby affecting one's decision to purchase sustainable apparel [61] According to MacInnis et al. [26], knowledge plays an integral role as an antecedent to the receiver's capacity for processing information. Maclnnis, Jaworski [62] claimed that knowledge modifies the reaction by affecting information processing and attentiveness to the message. Furthermore, Petty et al.'s [63] Elaboration Likelihood Model (ELM) sheds light on the relationship between environmental knowledge and attitude. As stipulated in ELM, high involvement can lead to a high degree of cognitive elaboration of the stimulus, which enables a high level of logical reasoning prior to decision-making. Therefore, it is believed that when consumers become more involved in fashion, they are more inclined to seek out new information on sustainable clothing products. As a result, they become more cognizant of sustainability and, ultimately, willing to purchase sustainable gear.

Based on this insight, the following hypotheses have been developed:

H1a: Fashion consciousness moderates the relationship between motivation and sustainable apparel purchase intention.

H2a: Fashion consciousness moderates the relationship between opportunity and sustainable apparel purchase intention.

H3a: Fashion consciousness moderates the relationship between ability and sustainable apparel purchase intention.

\subsection{Extended Research Model}

Drawing from the findings of the literature review, a conceptual framework representing an extended research model is proposed to investigate the purchase intention for sustainable apparel, as shown in Figure 1. This framework incorporates the MotivationOpportunity-Ability Theory [26], a sub-theory of Self-Determination Theory (SDT): Organismic Integration Theory [28], and the Regulatory Focus Theory [64,65].

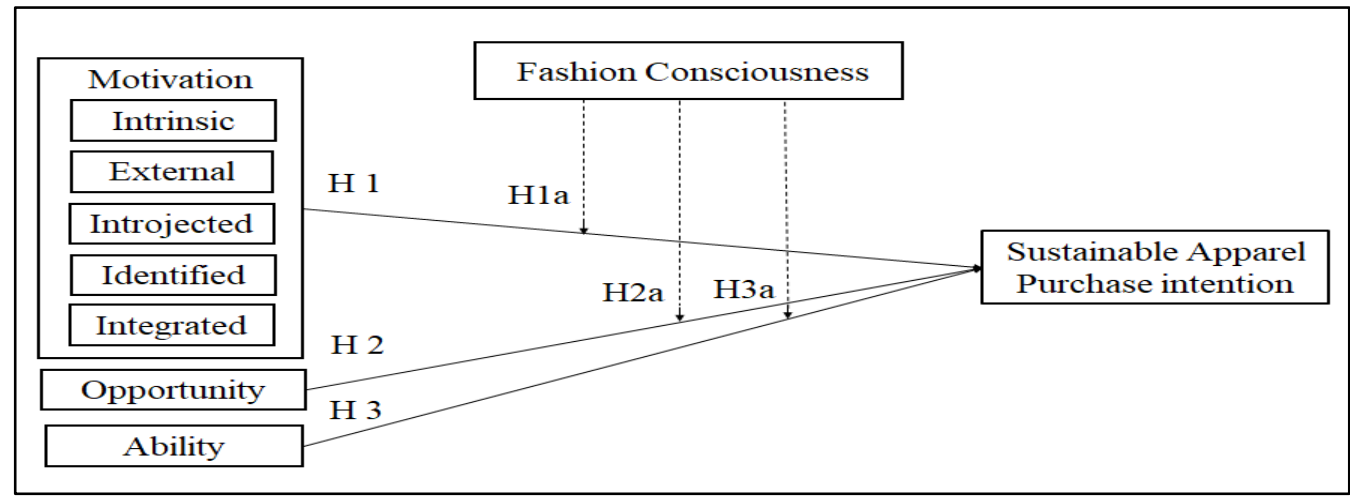

Figure 1. Conceptual framework of sustainable apparel purchase intention.

\section{Research Method}

\subsection{Questionnaire Design and Pre-Testing Study}

The data were gathered via a survey questionnaire. The suggested model was validated using trustworthy metrics adapted from previously validated scales. The motivation 
measurement, which consists of twenty items, was derived from Pelletier et al. [66]. The measurement of opportunity comprising five items was adapted from Tanner and Kast; Barbarossa $[67,68]$. The five-item ability assessment was adapted from La Trobe and Acott [69]. Meanwhile, a five-item measurement scale based on Kim and Karpova; Han and Stoel $[70,71]$ was used and modified to measure sustainable apparel purchase intention. This study adopted a five-item measure derived from Sprotles et al. and Parker et al. [72,73] to assess fashion consciousness. Seven-point and five-point Likert scales were utilised for all measures, respectively (see Table 1 and Appendix A). Participants were asked to provide information about their gender, age, occupation, level of education, income, and region.

Pre-testing was performed prior to data collection to determine the validity and reliability of the questionnaire functions [74]. During the pre-testing, various questionnaire components were thoroughly examined, taking into account all of the main components of the items, language, sequence, type and layout, and the complexity of questions and instructions. A panel of experts assessed the questionnaire, followed by a comprehensive analysis of accuracies [75]. The inaccurate components were revised, restructured, or removed based on the expert advice. To ensure the accuracy of the translation, the questionnaire was first translated into Malay and validated before being back-translated into English and validated. Both versions of the questionnaire were distributed to the respondents, who could respond in any of their preferred languages. The survey items are listed in Table 1.

Table 1. List of survey items.

\begin{tabular}{|c|c|}
\hline Items & Questions \\
\hline Motivation & Intrinsic \\
\hline INTR1 & $\begin{array}{l}\text { I am glad to learn new ways to help in preserving the environment through the } \\
\text { practise of sustainable clothing concept. }\end{array}$ \\
\hline INTR2 & $\begin{array}{l}\text { I am glad to help in improving the quality of the environment through the } \\
\text { practise of sustainable clothing concept. }\end{array}$ \\
\hline INTR3 & $\begin{array}{l}\text { I love the feeling I get when I do some things for the environment through the } \\
\text { practise of sustainable clothing concept. }\end{array}$ \\
\hline INTR4 & $\begin{array}{l}\text { I am glad to contribute to the environment through the practise of sustainable } \\
\text { clothing concept. }\end{array}$ \\
\hline Motivation & Integrated \\
\hline INTEG1 & $\begin{array}{l}\text { Taking care of the environment through the practise of sustainable clothing } \\
\text { concept has been an essential part of my life. }\end{array}$ \\
\hline INTEG2 & $\begin{array}{l}\text { In my opinion, self-care and environmental care through the practise of } \\
\text { sustainable clothing concept are attached together. }\end{array}$ \\
\hline INTEG3 & One of my ways in living my life is to practise the sustainable clothing concept. \\
\hline INTEG4 & $\begin{array}{l}\text { My environmental awareness through the practise of sustainable clothing } \\
\text { concept has become a fundamental part of who I am. }\end{array}$ \\
\hline Motivation & Identified \\
\hline IDEN1 & It is a sensible thing to practice sustainable clothing concept. \\
\hline IDEN2 & It is the way that I have chosen to practice sustainable clothing concept. \\
\hline IDEN3 & It is a reasonable thing to practice sustainable clothing concept. \\
\hline IDEN4 & I think it is a good idea to practice sustainable clothing concept. \\
\hline Motivation & Introjected \\
\hline INTRO1 & $\begin{array}{l}\text { I would regret it if I do not try hard in practising the sustainable clothing } \\
\text { concept. }\end{array}$ \\
\hline INTRO2 & I would feel guilty if I make no move to practise sustainable clothing concept. \\
\hline INTRO3 & I would feel bad if I make no move to practise sustainable clothing concept. \\
\hline INTRO4 & I would feel ashamed if I make no move to practise clothing apparel concept. \\
\hline
\end{tabular}


Table 1. Cont.

\begin{tabular}{|c|c|}
\hline Items & Questions \\
\hline Motivation & External \\
\hline EXTER1 & Other people would be mad if I do not practise sustainable clothing concept. \\
\hline EXTER2 & $\begin{array}{l}\text { I practise the sustainable clothing concept to receive recognition from other } \\
\text { people. }\end{array}$ \\
\hline EXTER3 & My friends encourage me to practise sustainable clothing concept. \\
\hline EXTER4 & To avoid being criticised, I practice sustainable clothing concept. \\
\hline \multicolumn{2}{|l|}{ Opportunity } \\
\hline OPPO1 & I could not afford to pay more to purchase sustainable clothing. \\
\hline OPPO2 & $\begin{array}{l}\text { I would not like to spend my time going to specialised stores to purchase } \\
\text { sustainable clothing products. }\end{array}$ \\
\hline OPPO3 & $\begin{array}{l}\text { I could not simply differentiate sustainable clothing from ordinary clothing } \\
\text { while shopping. }\end{array}$ \\
\hline OPPO4 & I need more time to find sustainable clothing products in the stores. \\
\hline OPPO5 & $\begin{array}{l}\text { I am not confident about the credibility of sustainable clothing labels and } \\
\text { certification. }\end{array}$ \\
\hline OPPO6 & $\begin{array}{l}\text { The recent activities of the fashion and textile industry have a negative effect } \\
\text { on the natural environment. }\end{array}$ \\
\hline OPPO7 & $\begin{array}{l}\text { The present activities of the fashion and textile industry are excessive and have } \\
\text { to be reduced. }\end{array}$ \\
\hline OPPO8 & $\begin{array}{l}\text { Everyone should adapt to use natural product/material rather than modifying } \\
\text { it to suit consumption. }\end{array}$ \\
\hline \multicolumn{2}{|l|}{ Ability } \\
\hline ABIL1 & It is necessary to change some basic attitudes to solve environmental problems. \\
\hline ABIL2 & Everyone should balance their lives with the natural environment. \\
\hline ABIL3 & The exploitation of nature often results in disastrous effects. \\
\hline ABIL4 & $\begin{array}{l}\text { Nowadays, many people have taken excessive interventions towards the } \\
\text { natural environment. }\end{array}$ \\
\hline ABIL5 & Everyone should feel empathy and be more concerned about the environment. \\
\hline \multicolumn{2}{|l|}{ Fashion } \\
\hline \multicolumn{2}{|l|}{ Consciousness } \\
\hline FC1 & I am most probably to have more than one of the newest style clothes. \\
\hline FC2 & I always keep up-to-date with current fashion trends. \\
\hline FC3 & I really put attention on fashionable and attractive clothing styling. \\
\hline FC4 & I shop at different stores to get a variety of clothing selections. \\
\hline FC5 & I enjoy purchasing new and attractive clothing. \\
\hline \multicolumn{2}{|l|}{ Purchase } \\
\hline SAPI1 & I plan to buy sustainable clothes in the future. \\
\hline SAPI2 & I will try to buy sustainable clothes in the future. \\
\hline SAPI3 & I will make an effort in buying sustainable clothes in the future. \\
\hline SAPI4 & $\begin{array}{l}\text { I plan to buy or consider buying sustainable clothes if I come across them in } \\
\text { the stores. }\end{array}$ \\
\hline SAPI5 & $\begin{array}{l}\text { If I see a retail store selling/implementing sustainable apparel practice, I } \\
\text { intend to visit the store to purchase a product. }\end{array}$ \\
\hline
\end{tabular}

\subsection{Sample Characteristics and Procedures}

Millennials were chosen as respondents in this survey on the grounds that they would likely account for the majority of future purchasing power and were more concerned with environmental issues and sustainable lifestyles [76]. They have a greater understanding of the environment than prior generations, having been nurtured on a regular diet of environmental awareness [77]. Besides, companies preferred to target Millennials due to the segment's high spending power and peer pressure $[78,79]$.

A purposive sampling method was used to select participants based on their readiness and potential to contribute pertinent information about the phenomenon under investigation. Knowledge of the research area and related literature is necessary to accomplish 
the study objective [80]. The study selected Malaysia's top urban areas: Kuala Lumpur, Putrajaya, Petaling Jaya, Johor Bahru, Timur Laut in Penang, and Melaka Tengah. The questionnaire was distributed online from 13 August to 10 November 2020 via email and Facebook (FB) groups that demonstrated strong support for the sustainable fashion movement. The survey invitation on FB was reposted twice and was supported by sustainable fashion practitioners in Malaysia, including Fashion Revolution, Icycle, CRC Group, and numerous sustainable fashion practitioners.

Respondents must answer the screening questions before being selected as one of the respondents. Only respondents from the millennial generation who lived in one of the top six urban regions were eligible to participate in the study. Respondents were requested to provide information on their purchase intention, as well as motivation, opportunity, aptitude, and fashion consciousness. Finally, their demographic information was collected.

Out of 339 responses received, 324 responses were usable. Table 2 details the respondents' demographic information. The majority of the respondents were females (61.73 per cent) and of Malay ethnicity (78.4 per cent). The percentage of Malay respondents is fairly similar to data on the Malaysian population, which is dominated by the Millennial Malay ethnic group, with nearly 67 per cent of them using the internet and social media [81]. Half of the respondents were between 27 and 32 years old (53.4 per cent); 41.67 per cent held a bachelor's degree; and 38.58 per cent were public servants. Most respondents earned between RM 2501 and RM 5000 (USD 600 to USD 1200) a month (40.43 per cent).

Table 2. Demographics of respondents.

\begin{tabular}{|c|c|c|c|}
\hline \multicolumn{2}{|c|}{ Demographic Variables } & \multirow{3}{*}{$\begin{array}{c}\text { Frequency } \\
124 \\
200\end{array}$} & \multirow{3}{*}{$\begin{array}{c}\text { Percentage } \mathbf{( \% )} \\
38.27 \\
61.73\end{array}$} \\
\hline & Male & & \\
\hline Gender & Female & & \\
\hline \multirow{4}{*}{ Ethnicity } & Malay & 254 & 78.4 \\
\hline & Chinese & 25 & 7.72 \\
\hline & Indian & 27 & 8.33 \\
\hline & Others & 18 & 5.56 \\
\hline \multirow{3}{*}{ Age } & 21-26 years old & 109 & 33.64 \\
\hline & $27-32$ years old & 173 & 53.4 \\
\hline & 33-38 years old & 42 & 12.96 \\
\hline \multirow{5}{*}{ Occupation } & Government Sector Employee & 125 & 38.58 \\
\hline & Private Sector Employee & 105 & 32.41 \\
\hline & Self-Employed & 68 & 20.99 \\
\hline & Student & 17 & 5.25 \\
\hline & Not working & 9 & 2.8 \\
\hline \multirow{6}{*}{ Education Level } & Certificate & 9 & 2.8 \\
\hline & SPM & 35 & 10.8 \\
\hline & Diploma & 57 & 17.59 \\
\hline & Bachelor's degree & 135 & 41.67 \\
\hline & Master's degree & 74 & 22.84 \\
\hline & $\mathrm{PhD}$ & 14 & 4.32 \\
\hline \multirow{6}{*}{ Income } & Below RM 1001(USD 240) & 19 & 5.86 \\
\hline & $\begin{array}{l}\text { RM 1001-RM } 2500 \\
\text { (USD 240-USD 600) }\end{array}$ & 125 & 38.58 \\
\hline & $\begin{array}{l}\text { RM 2501-RM } 5000 \\
\text { (USD 600-USD1200) }\end{array}$ & 131 & 40.43 \\
\hline & $\begin{array}{l}\text { RM 5001-RM 7500 } \\
\text { (USD 1200-USD 1800) }\end{array}$ & 20 & 6.17 \\
\hline & RM 7501-RM 9500 & 25 & 7.71 \\
\hline & $\begin{array}{l}\text { RM } 9501 \text { and above } \\
\text { (USD 2400) }\end{array}$ & 4 & 1.23 \\
\hline
\end{tabular}




\subsection{Statistical Techniques}

The data was analysed using the statistical software SEM-PLS (3.2.8), which is commonly used in the social sciences $[75,82]$. SEM-PLS was employed to extract the multivariate qualities of the data to ease the analysis of the measurement and structural models.

\section{Results}

\subsection{Measurement Model}

The assessment of the measurement model quantifies the individual loading of each measurement item [83]. As this study involved the evaluation of the reflective measurement model, several metrics were used to assess the intervention, including reliability, convergent validity, and discriminant validity [84]. It is critical to assess the composite reliability in order to weigh individual indicators according to their loadings and preferred reliability approach [84]. The assessment for discriminant validity considers the Fornell-Larcker criterion, cross-loadings, and heterotrait-monotrait (HTMT).

Table 3 summarises the results of the confirmatory factor analysis performed on the measurement model, as well as standardised factor loadings of the construct items. In order to establish the convergent validity of the data, three conditions must be met [85]. The factor loading of each construct item must be at least 0.60 ; the average variance extracted (AVE) of each construct should be greater than 0.50 ; the composite reliability of each construct should be greater than 0.70 [82]. Table 3 shows all standardised factor loadings ranged from 0.606 to 0.933 , which were acceptable. However, due to the low value of AVE for the "Ability" construct (0.478), one of its items (ABIL1) was removed. As a result, the AVE value for "Ability" increased to 0.504 , which was greater than the cut-off point of 0.50 . With that, the AVE values of each construct exceeded the threshold value. Meanwhile, with the exception of the values of fashion consciousness and buy intention, every composite reliability ranged between 0.748 and 0.876 , exceeding 0.70 . Thus, the Cronbach's alpha coefficients greater than 0.7 was used as the threshold.

Table 3. Fitness of the measurement model.

\begin{tabular}{|c|c|c|c|c|c|}
\hline Constructs & Items & $\begin{array}{l}\text { Factor } \\
\text { Loadings }\end{array}$ & $\begin{array}{l}\text { Number of } \\
\text { Items Deleted }\end{array}$ & AVE & CR \\
\hline \multirow{5}{*}{ Intrinsic } & INTR1 & 0.933 & & \multirow{4}{*}{0.939} & \multirow{4}{*}{0.795} \\
\hline & INTR2 & 0.829 & & & \\
\hline & INTR3 & 0.885 & & & \\
\hline & INTR4 & 0.917 & & & \\
\hline & EXTER1 & 0.911 & & \multirow{4}{*}{0.950} & \multirow{4}{*}{0.825} \\
\hline \multirow{3}{*}{ External } & EXTER2 & 0.906 & & & \\
\hline & EXTER3 & 0.911 & & & \\
\hline & EXTER4 & 0.904 & & & \\
\hline \multirow{4}{*}{ Introjected } & INTRO1 & 0.893 & & \multirow{4}{*}{0.937} & \multirow{4}{*}{0.789} \\
\hline & INTRO2 & 0.876 & & & \\
\hline & INTRO3 & 0.890 & & & \\
\hline & INTRO4 & 0.894 & & & \\
\hline \multirow{5}{*}{ Identified } & IDEN1 & 0.901 & & \multirow{5}{*}{0.935} & \multirow{5}{*}{0.783} \\
\hline & IDEN2 & 0.885 & & & \\
\hline & IDEN3 & 0.892 & & & \\
\hline & IDEN4 & 0.860 & & & \\
\hline & INTEG1 & 0.909 & & & \\
\hline \multirow{3}{*}{ Integrated } & INTEG2 & 0.914 & & \multirow{3}{*}{0.949} & \multirow{3}{*}{0.824} \\
\hline & INTEG3 & 0.905 & & & \\
\hline & INTEG4 & 0.903 & & & \\
\hline \multirow{5}{*}{ Opportunity } & OPPO1 & 0.851 & & \multirow{5}{*}{0.937} & \multirow{5}{*}{0.748} \\
\hline & OPPO2 & 0.858 & & & \\
\hline & OPPO3 & 0.836 & & & \\
\hline & OPPO4 & 0.869 & & & \\
\hline & OPPO5 & 0.909 & & & \\
\hline
\end{tabular}


Table 3. Cont.

\begin{tabular}{|c|c|c|c|c|c|}
\hline Constructs & Items & $\begin{array}{c}\text { Factor } \\
\text { Loadings }\end{array}$ & $\begin{array}{c}\text { Number of } \\
\text { Items Deleted }\end{array}$ & AVE & CR \\
\hline \multirow{8}{*}{ Ability } & ABIL1 & 0.606 & & \multirow{8}{*}{0.504} & \multirow{8}{*}{0.876} \\
\hline & ABIL2 & 0.687 & & & \\
\hline & ABIL3 & 0.650 & & & \\
\hline & ABIL4 & 0.742 & & & \\
\hline & ABIL5 & 0.739 & & & \\
\hline & ABIL6 & 0.759 & & & \\
\hline & ABIL7 & 0.634 & & & \\
\hline & ABIL8 & 0.700 & & & \\
\hline \multirow{5}{*}{$\begin{array}{c}\text { Fashion } \\
\text { Consciousness }\end{array}$} & FC1 & 0.816 & & \multirow{5}{*}{0.888} & \multirow{5}{*}{0.615} \\
\hline & FC2 & 0.766 & & & \\
\hline & FC3 & 0.807 & & & \\
\hline & FC4 & 0.718 & & & \\
\hline & FC5 & 0.808 & & & \\
\hline \multirow{5}{*}{$\begin{array}{l}\text { Purchase } \\
\text { Intention }\end{array}$} & SAPI1 & 0.816 & & \multirow{5}{*}{0.883} & \multirow{5}{*}{0.601} \\
\hline & SAPI2 & 0.757 & & & \\
\hline & SAPI3 & 0.791 & & & \\
\hline & SAPI4 & 0.715 & & & \\
\hline & SAPI5 & 0.794 & & & \\
\hline
\end{tabular}

Based on the criteria prescribed by Fornell et al. [86], the model appears to demonstrate discriminant validity. The diagonals of the Fornell-Larcker of each of the variables are the square root of the AVE with the latent variable correlations. The square root of the AVE for each construct was greater than the correlation with the other constructs [83]. Meanwhile, Henseler et al. [87] suggested that the heterotrait-monotrait (HTMT) ratio can further identify the lack of discriminant validity and is as superior as the Fornell-Larker criteria, considering it "offers the best balance between high detection and low arbitrary violation" [88]. Based on Table 4, none of the confidence intervals captured one. Moreover, the bias associated with the bootstrapping estimates is unlikely as the confidence intervals for the HTMT values provide additional evidence of discriminant validity. Thus, it is confirmed that all constructs were distinctively different from one another, which also confirmed the discriminant validity [87]. Alternatively, the measures of reliability and validity of the variables are latent constructs. This approach has to be established before assessing the structural model [84].

Table 4. The Fornell-Larcker of each of the variables.

\begin{tabular}{|c|c|c|c|c|c|c|c|c|c|}
\hline Variables & $\frac{2}{2}$ & 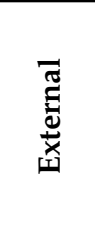 & 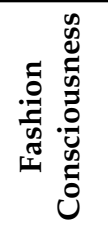 & & 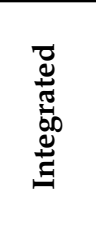 & 岇 & 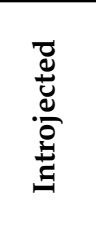 & 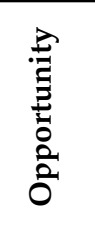 & 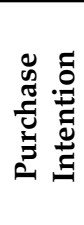 \\
\hline Ability & 0.710 & & & & & & & & \\
\hline External & 0.172 & 0.908 & & & & & & & \\
\hline $\begin{array}{c}\text { Fashion } \\
\text { Consciousness }\end{array}$ & 0.272 & 0.223 & 0.784 & & & & & & \\
\hline Identified & 0.217 & 0.553 & 0.259 & 0.885 & & & & & \\
\hline Integrated & 0.220 & 0.498 & 0.182 & 0.532 & 0.908 & & & & \\
\hline Intrinsic & 0.172 & 0.468 & 0.176 & 0.581 & 0.628 & 0.892 & & & \\
\hline Introjected & 0.146 & 0.655 & 0.162 & 0.539 & 0.493 & 0.382 & 0.888 & & \\
\hline Opportunity & 0.354 & 0.359 & 0.215 & 0.395 & 0.453 & 0.329 & 0.326 & 0.865 & \\
\hline Purchase Intention & 0.495 & 0.425 & 0.384 & 0.469 & 0.431 & 0.383 & 0.348 & 0.594 & 0.775 \\
\hline
\end{tabular}

\subsection{Higher-Order Construct}

Prior to assessing the structural model, it is pertinent to note that the purchase intention (outcome variable) in this study is specified as a second-order reflective construct that is 
partly determined by the construct of "Motivation" from the following five first-order reflective factors: intrinsic, external, introjected, identified, and integrated motivation. The second-order construct is measured using the two-stages approach [89], which was recommended by Hair et al.; Henseler et al. $[84,87]$ as the ideal approach to analyse the reflective-formative type of higher-order model (HOM). Based on the results of convergent validity and reliability demonstrated in Table 5 , all values exceeded the recommended threshold (outer loadings $>0.4, \mathrm{AVE}>0.5$, and $\mathrm{CR}>0.7$ ). Importantly, this revealed the goodness of measure for the reflected second-order construct within the scope of this research.

Table 5. Convergent validity: loadings, average variance extracted, and composite reliability of second-order construct.

\begin{tabular}{llcccc}
\hline & Variables & & Type & AVE & CR \\
\hline \multirow{4}{*}{ Motivation } & & & 0.801 & & \\
& Reflective- & High-Order & 0.823 & & \\
& formative & Construct & 0.800 & 0.7912 & 0.8933 \\
& & & 0.771 & & \\
\hline
\end{tabular}

\subsection{Structural Model}

After obtaining the adequacy of the measurement model, the structural model was evaluated. As proposed in the Structural Equation Model (SEM) framework, five criteria were examined to explain the impacts of exogenous latent variables on endogenous latent variables. In the succeeding steps, coefficient of determination $\left(\mathrm{R}^{2}\right)$, effect size $\left(\mathrm{f}^{2}\right)$, blindfolding, and predictive relevance $\left(\mathrm{Q}^{2}\right)$ were performed [74].

Using $R^{2}$ as a goodness-of-fit metric from regression, a measure from discriminant analysis (classification matrix) can be utilised in conjunction with the chi-square-based measure of fit to assess overall prediction accuracy [82]. A higher $\mathrm{R}^{2}$ value indicates that the structural model's predictive ability has improved. The $\mathrm{R}^{2}$ in Table 6 was 0.536 , indicating that 53.6 per cent of the model explained the sustainable apparel purchase intention among millennials in Malaysia, while 46.4 per cent was attributed to other factors. Statistically, an $R^{2}$ value above 0.50 is considered moderate in marketing research and consumer behaviour [83].

Table 6. Fitness of the structural model.

\begin{tabular}{|c|c|c|c|c|c|c|c|c|}
\hline Hypothesis & Direct Effect & $\beta$ & $\begin{array}{l}\text { Std. } \\
\text { Error }\end{array}$ & $t$-Value & $p$-Value & $\mathbf{R}^{2}$ & $Q^{2}$ & $\mathbf{f}^{2}$ \\
\hline $\mathrm{H} 1$ & Motivation $\rightarrow$ Purchase Intention & 0.255 & 0.048 & $5.959 * *$ & 0.000 & & & 0.129 \\
\hline $\mathrm{H} 2$ & Opportunity $\rightarrow$ Purchase Intention & 0.343 & 0.053 & $6.706^{* *}$ & 0.000 & 0.536 & 0.229 & 0.181 \\
\hline $\mathrm{H} 3$ & Ability $\rightarrow$ Purchase Intention & 0.267 & 0.056 & $5.397^{* *}$ & 0.000 & & & 0.163 \\
\hline
\end{tabular}

Note: ${ }^{* *} p<0.05$

A blindfolding technique was used to conduct the predictive relevance $\left(\mathrm{Q}^{2}\right)$ analysis. Blindfolding employs a cross-validation technique and reports construct and indicator crossvalidated communality and cross-validated redundancy [90]. When the $\mathrm{Q}^{2}$ value surpasses zero, the model is regarded as well-constructed and has predictive relevance $[83,84,87]$. The $Q^{2}$ value $(0.229)$ has been in line with the standard and is deemed to possess medium predictive relevance as suggested by Cohen [91].

Understanding the impact of effect size prior to examining the role of sample size has been crucial. Effect size $\left(\mathrm{f}^{2}\right)$ represents a standardised measure used to measure differences between group means. It has often been presented as the difference between group means divided by the standard deviation [82]. While the sample size is usually the most controllable factor for researchers, it can significantly affect power in many instances, especially when the alpha level is specified and the effect size is identified. Likewise, 
increased sample size can reduce sampling error and increase the sensitivity (power) of the test [84]. In this study, $\mathrm{f}^{2}$ was assessed using a rule of thumb, whereby $\mathrm{f}^{2}$ values of 0.02 , 0.15 , and 0.35 represent small, medium, and large effects, respectively [91]. A complete analysis of the structural model is summarised in Table 6, indicating medium effect sizes of each independent variable on purchase intention.

\subsection{Moderating Effect of Fashion Consciousness}

The product indicator approach, a typical approach for creating the interaction term in regression-based analyses [74] of PLS-SEM, was used to investigate the moderating effect of fashion consciousness. This approach involves multiplying each indicator of the exogenous latent variable with each indicator of the moderator variable [92]. This is a promising tool to determine the moderating effects when the moderator variable is reflective [83]; thus, it was used in this study.

The findings of this research revealed that fashion consciousness moderated all the relationships between all the independent variables (motivation, opportunity, ability) and sustainable apparel purchase intention Table 7 shows all values exceeded the recommended threshold ( $p$-value $<0.05, t$-value $>1.645$ ) with a small effect size of 0.021 , 0.021 , and 0.028 for H1a, H2a, and H3a, respectively. Meanwhile, as seen in Appendix A portrayed Tables A1-A3 and Figures A1-A4, all hypotheses exhibited an increase in $\mathrm{R}^{2}$ when the moderator was included. Dawson [93] suggested that the interaction plot may be applied to analyse the moderating effect (potrayed in Figure 2). On the line of reasoning, interaction can be meaningful even with a small interaction effect if the beta result changes significantly [92].

Table 7. Hypotheses of indirect effects.

\begin{tabular}{cccccccc}
\hline Hypothesis & Indirect Effect & $\beta$ & Std. Error & $t$-Value & $p$-Value & $\mathbf{f}^{2}$ & Effect Size \\
\hline H1a & $\begin{array}{c}\text { Motivation * Fashion Consciousness } \rightarrow \\
\text { Purchase Intention }\end{array}$ & 0.105 & 0.045 & $2.342^{* *}$ & 0.010 & 0.021 & Small \\
H2a & $\begin{array}{c}\text { Opportunity * Fashion Consciousness } \\
\rightarrow \text { Purchase Intention }\end{array}$ & 0.074 & 0.032 & $2.323^{* *}$ & 0.010 & 0.021 & Small \\
H3a & $\begin{array}{c}\text { Ability * Fashion Consciousness } \rightarrow \\
\text { Purchase Intention }\end{array}$ & 0.133 & 0.041 & $3.273^{* *}$ & 0.001 & 0.028 & Small \\
\hline
\end{tabular}

Note: ${ }^{* *} p<0.05,{ }^{*} p<0.01$.

H1a: Motivation * Fashion Consciousness $\rightarrow$ Purchase Intention

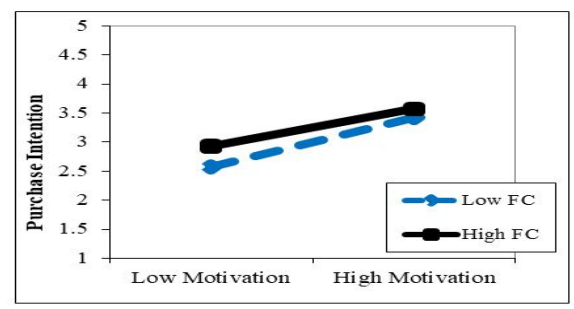

(a)
H2a: Opportunity * Fashion Consciousness $\rightarrow$ Purchase Intention

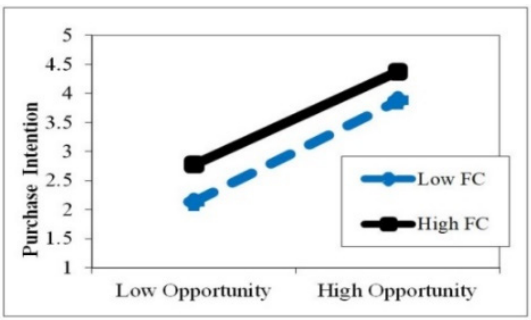

(b)
H3a: Ability * Fashion Consciousness $\rightarrow$ Purchase Intention

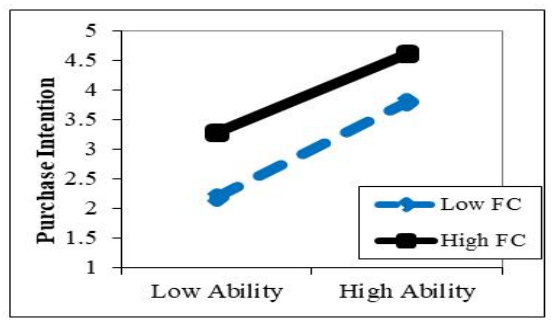

(c)

Figure 2. The interaction of the moderating effect using Dawson (2014).

\section{Discussion}

As shown in Table 8, the results of all the hypotheses testing revealed positive influences of all variables on sustainable apparel purchase intention. The findings are consistent with [93-95], whereby these earlier studies highlighted the positive relationship of the MOA function on purchase intention. 
Table 8. Hypothesis testing results.

\begin{tabular}{ccccc}
\hline Hypothesis & Path & $\beta$ & $p$-Value & Hypothesis \\
\hline H1 & Motivation $\rightarrow$ Purchase Intention & 0.255 & 0.000 & Supported \\
H2 & Opportunity $\rightarrow$ Purchase Intention & 0.343 & 0.000 & Supported \\
H3 & Ability $\rightarrow$ Purchase Intention & 0.267 & 0.000 & Supported \\
H1a & Motivation * fashion consciousness $\rightarrow$ Purchase Intention & 0.105 & 0.010 & Supported \\
H2a & Opportunity * Fashion Consciousness $\rightarrow$ Purchase Intention & 0.074 & 0.010 & Supported \\
H3a & Ability * fashion consciousness $\rightarrow$ Purchase Intention & 0.133 & 0.001 & Supported \\
\hline
\end{tabular}

Sustainable fashion appears to be appealing among Millennials with a higher education since the majority of respondents in this study held a bachelor's degree or higher qualifications (86.42 per cent). This finding is in line with Mohd Suki and Mohd Suki's [96] and Kumar et al.'s [97] assertions that people with a higher education background generally have more knowledge and understanding of ecological concerns and, thus, are more capable of comprehending sustainable consumption. Apart from that, the findings in [98] on sustainable apparel also suggested that consumer knowledge and awareness of the environment and perception of green clothing could be used to predict green clothing purchase intention. High fashion-conscious customers would be able to identify themselves with sustainable consumption if they are satisfied with their interactions with sustainable products. The satisfaction would drive them to be loyal green consumers.

The present study also highlighted the barriers of availability, accessibility, and affordability related to sustainable fashion. These barriers could be overcome by using the opportunity and ability constructs of the MOA model. Given that the sustainable fashion trend in Malaysia was still in its infancy, there were few options and products on the market $[99,100]$. In light of this barrier, the slow adoption of consumers in sustainable apparel can be attributed in part to a lack of market supply. Many practitioners failed to capitalise on green consumers because they were unsure of the characteristics and behaviours of eco-friendly customers [18]. Therefore, a more thorough and detailed market analysis on consumers' needs and preferences for sustainable products is required to address the concern. Meanwhile, more sustainable certifications have been introduced to advocate customers' purchase of sustainable products [92]. Environmental education and strict quality assurance through certifications are essential for increasing consumer confidence in sustainable products and, as a result, promoting green consumption among buyers [101]. These are some examples of notable labels and certifications include the following: Global Organic Textile Standard (GOTS), SCS (Standard Apparel Coalition Standard), and Cradle to Cradle. Such certifications or labels would enable consumers to act on the intention of purchasing sustainable clothing.

Nonetheless, the above findings would have been influenced by a sustainable pattern of consumption, which can vary depending on consumer demography, geography, economic stability, and new products $[47,102,103]$. As previously mentioned, the national cultural orientation has a significant impact on the value of sustainable consumption. Since Malaysia upholds collectivism and low individualism [104], it is necessary to further elaborate the results with consideration to the context of Malaysia. While some consumption is based on personality and personal preference [105], Halder et al. [106] found that consumers with a collective and long-term development orientation were more disposed to green consumption than those who valued individualism and a short-term development orientation. Under the influence of a multicultural society with shared values and commonalities, collectivism allows consumers to make decisions based on a sense of harmony and concern for others [107]. This interdependence mentality may trigger consumer motivation for green purchases and has a profound impact on the perceived value of green consumption. Culture impacts one's values and ethical ideologies [108]. Culture plays an important role in influencing consumer behaviour of sustainable products, both directly and indirectly $[27,109,110]$. 


\section{Conclusions}

This empirical study was carried out to replicate the former studies in identifying the fashion industry as one of the most polluting industries [1-3]. This study examined the hypotheses in relation to motivation, opportunity, ability, and the moderating effect of fashion consciousness on purchase intentions for sustainable apparel. In response to the deterioration of the environment and the growing urgency of sustainability, the fashion industry has the utmost responsibility to become more sustainable. Similarly, consumers have to shift from conventional products to green products in their consumption to continue the momentum for sustainable fashion. For consumers, the post-pandemic period denotes a "green" wake-up call [98]. Consumers demand assurances that all aspects of a production process, from the procurement of raw materials to the finished products, are conducted in a manner that respects human and environmental health. In line with this notion, marketers, producers, manufacturers, and policymakers should take the leadership role and incorporate sustainability strategy into their core business practices so that the SDGs can become a reality.

The study presents a contribution to the knowledge and practice of sustainable consumption. For marketing and consumer behaviour research, the study provides an extended model, incorporating the MOA theory and SDT theory. Besides, the importance of equipping customers with more sustainable knowledge and acknowledging the national culture would shed light on consumer sustainable consumption in a non-Western country. The findings may help to create a more comprehensive picture of the antecedents and outcomes of sustainable apparel purchase intentions. Developing countries can protect the environment and foster sustainability by selling green products across emerging countries to accelerate sustainable consumption [21]. In terms of practice, Wai et al. [111] postulated that Malaysia is considered a "pioneer" in Asia regarding promoting sustainable consumption. Given that the majority of consumers are looking for high-quality and long-lasting products, strong correlations can be established between style, value, and the environment to influence the consumers' perception towards sustainable consumption across different brands, not just in the fashion category [112]. Thus, for practitioners (companies, merchants, and marketers), evaluating motivation, the capacity to learn environmental knowledge, and the opportunities available in the current marketplaces should aid them in achieving the SDGs. Sustainable garments will not be widely accepted if product design is not improved, access to fashion remains difficult, customers are sceptical of environmental promises, and consumers lack "green" knowledge. Despite Malaysia's modest growth, an increasing number of apparel companies are entering the sustainable apparel market. This has been demonstrated by several viable start-ups such as KANOE, Nukleus Wear, Zibossa, and Real-M [100]. Simultaneously, the addition of new clothing collection points, such as recycling bins and home collection services, has resulted in an increase in clothesrecycling rates [111]. These positive changes support the research findings that the current element of fashion consciousness can strengthen the relationship between opportunity and the purchase of sustainable apparel. Apart from that, governments should continue cultivating and promoting environmental consciousness through education. Research has indicated that consumers generally have limited information and little product knowledge about sustainable apparel when they have the intention of purchasing it. Therefore, delivering the right information to consumers is hugely vital to increasing their environmental knowledge and enhancing their purchase intentions.

\section{Limitations and Further Research}

However, the findings of this study are subjected to some limitations. Since the data collection focused on the top six urban areas in Malaysia, Kuala Lumpur, Putrajaya, Petaling Jaya in Selangor, Johor Bahru, Timur Laut in Penang, and Melaka Tengah in Malacca, the results may represent the whole Millennial generation of Malaysia. The area of survey distribution is crucial to gaining quality responses [113]. Thus, future studies should broaden the area to include all urban regions in Malaysia and other countries with 
comparable urban areas and national cultures to enhance the understanding of sustainable consumption. Furthermore, although much of this research work may be replicated in other developing countries, future studies should include other theories or dimensions that cover internal, external, and social dimensions [114-116]. In addition, future research may want to explore other types of sustainable fashion products, such as jewellery and high-end items. Due to the fact that sustainability in the fashion industry is still in its infancy, numerous other topics have remained unexplored to date [15].

Author Contributions: Conceptualization, N.N.H., Z.S. and A.M.; methodology, N.N.H., Z.S. and A.M.; software, N.N.H. and H.S.A.S.; validation, Z.S. and A.M.; formal analysis, N.N.H.; investigation, N.N.H. and H.S.A.S.; resources, Z.S.; data curation, N.N.H. and H.S.A.S.; writing-original draft preparation, N.N.H.; writing-review and editing, Z.S.; visualization, N.N.H. and H.S.A.S.; supervision, Z.S. and A.M.; project administration, N.N.H.; funding acquisition, Z.S. All authors have read and agreed to the published version of the manuscript.

Funding: This research received no external funding.

Institutional Review Board Statement: Not applicable.

Informed Consent Statement: Informed consent was obtained from all subjects involved in the study.

Data Availability Statement: The datasets analysed in this study are available upon request from the authors.

Acknowledgments: The authors would like to thank Sonali Diddi from the School of Global Environmental Sustainability, Colorado State University, USA whose critical comments and suggestions on the earlier draft helped improve and clarify this manuscript.

Conflicts of Interest: The authors declare no conflict of interest.

\section{Appendix A. The Path Coefficient Value for Moderating Variables}

H1a: Beta Path Coefficient Value for Moderating Variable (Motivation * Fashion consciousness $\rightarrow$ Purchase Intention).

Table A1. Beta Path Coefficient of Moderating Variables (Motivation * Fashion consciousness $\rightarrow$ Purchase Intention).

\begin{tabular}{ccccc}
\hline & Included & Excluded & f-Squared & Effect Size \\
\hline R-squared & 0.360 & 0.347 & 0.021 & Small \\
\hline
\end{tabular}

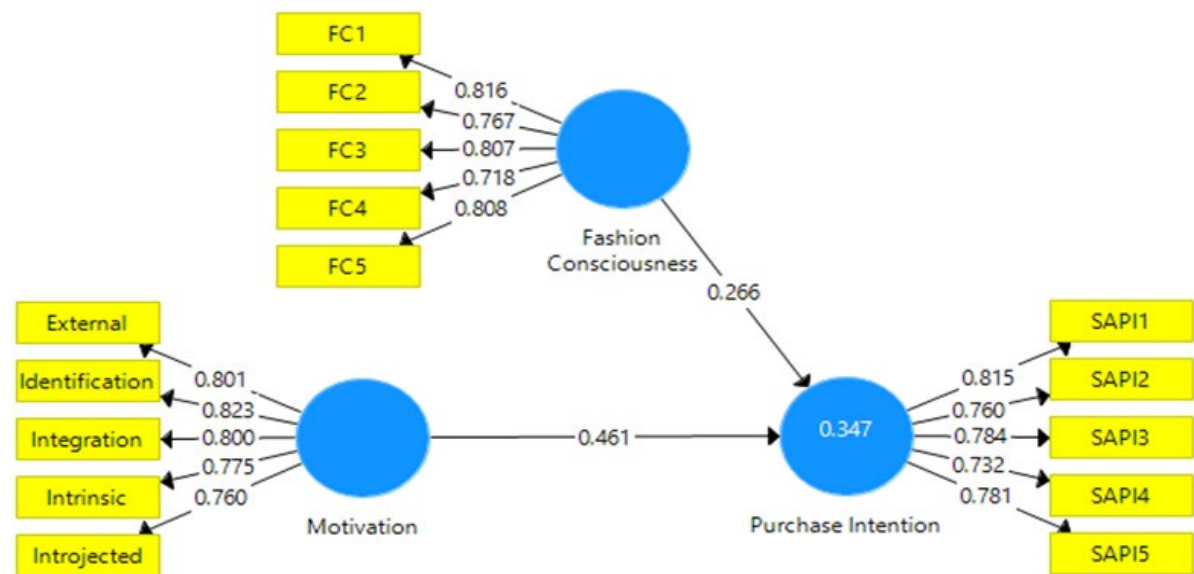

Figure A1. The construct before the inclusion of moderator. 


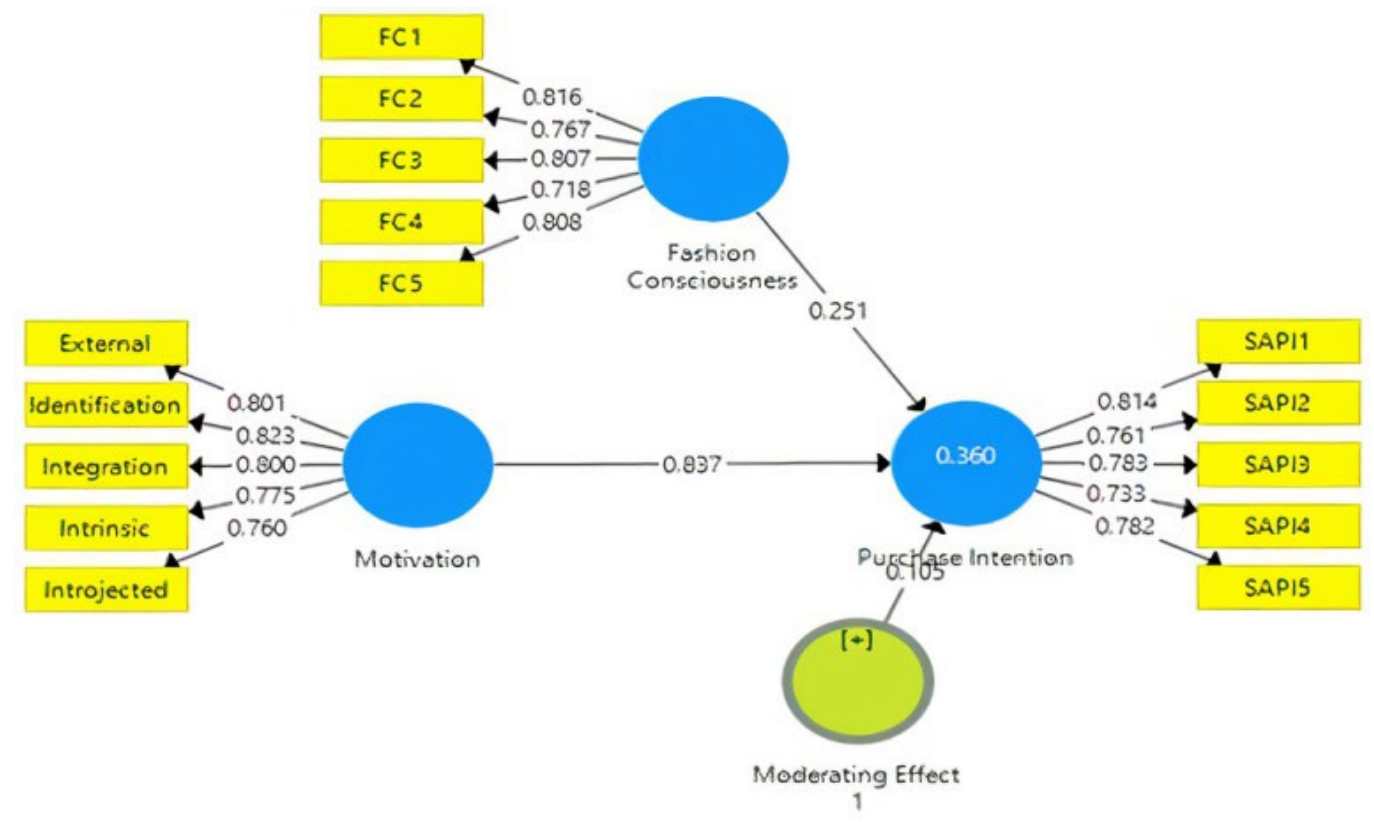

Figure A2. The construct after the inclusion of moderator.

H2a: Beta Path Coefficient Value for Moderating Variable (Opportunity * Fashion Consciousness $\rightarrow$ Purchase Intention).

Table A2. Beta Path Coefficient of Moderating Variables Opportunity * Fashion Consciousness $\rightarrow$ Purchase Intention).

\begin{tabular}{ccccc}
\hline & Included & Excluded & f-Squared & Effect Size \\
\hline R-squared & 0.436 & 0.425 & 0.021 & Small \\
\hline
\end{tabular}

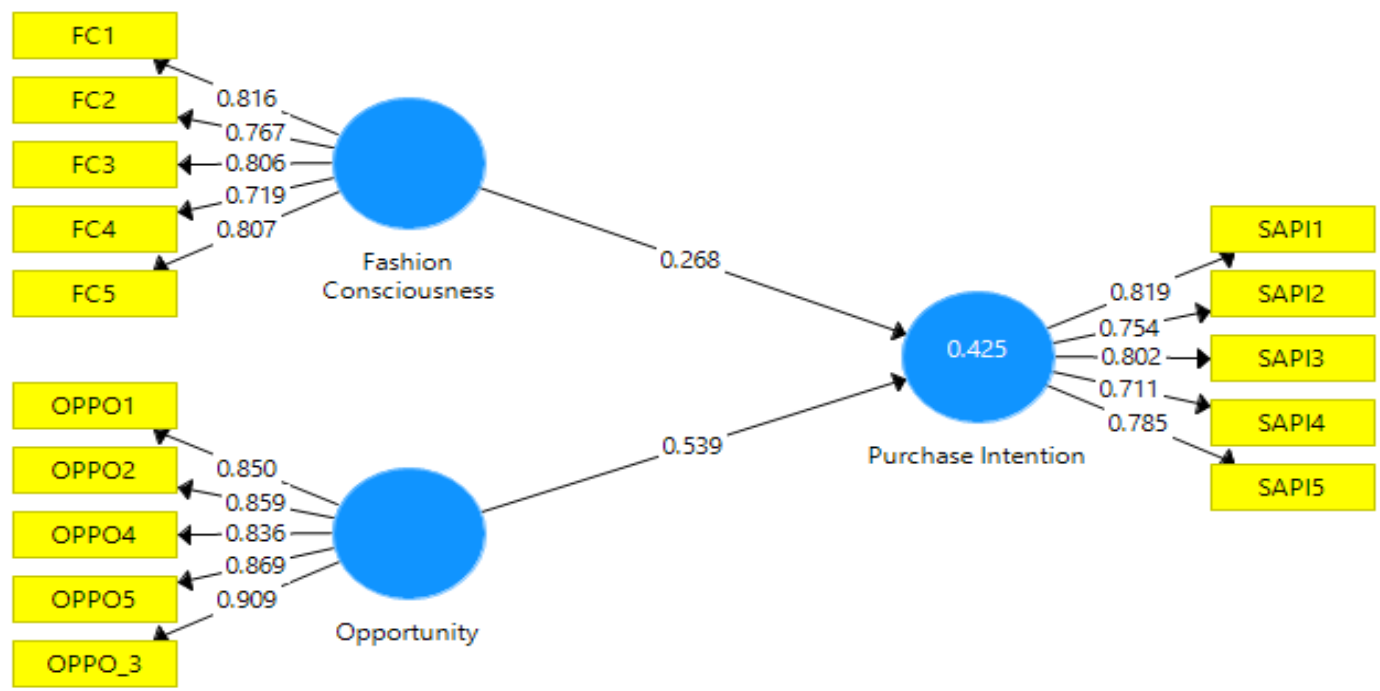

Figure A3. The construct before the inclusion of moderator. 


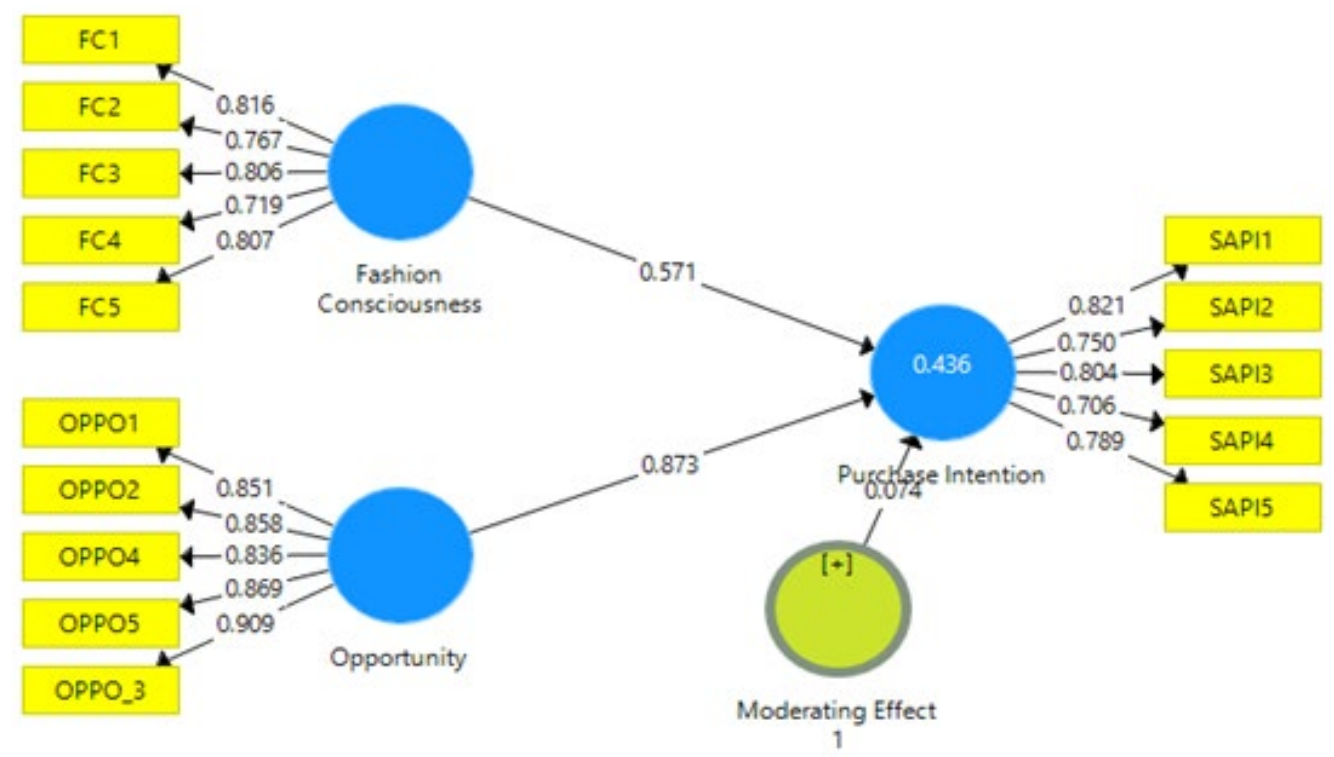

Figure A4. The construct after the inclusion of moderator.

H3a: Beta Path Coefficient Value for Moderating Variable (Ability * Fashion Consciousness $\rightarrow$ Purchase Intention).

Table A3. Beta Path Coefficient of Moderating Variables Opportunity * Fashion Consciousness $\rightarrow$ Purchase Intention).

\begin{tabular}{ccccc}
\hline & Included & Excluded & f-Squared & Effect Size \\
\hline R-squared & 0.333 & 0.314 & 0.028 & Small \\
\hline
\end{tabular}

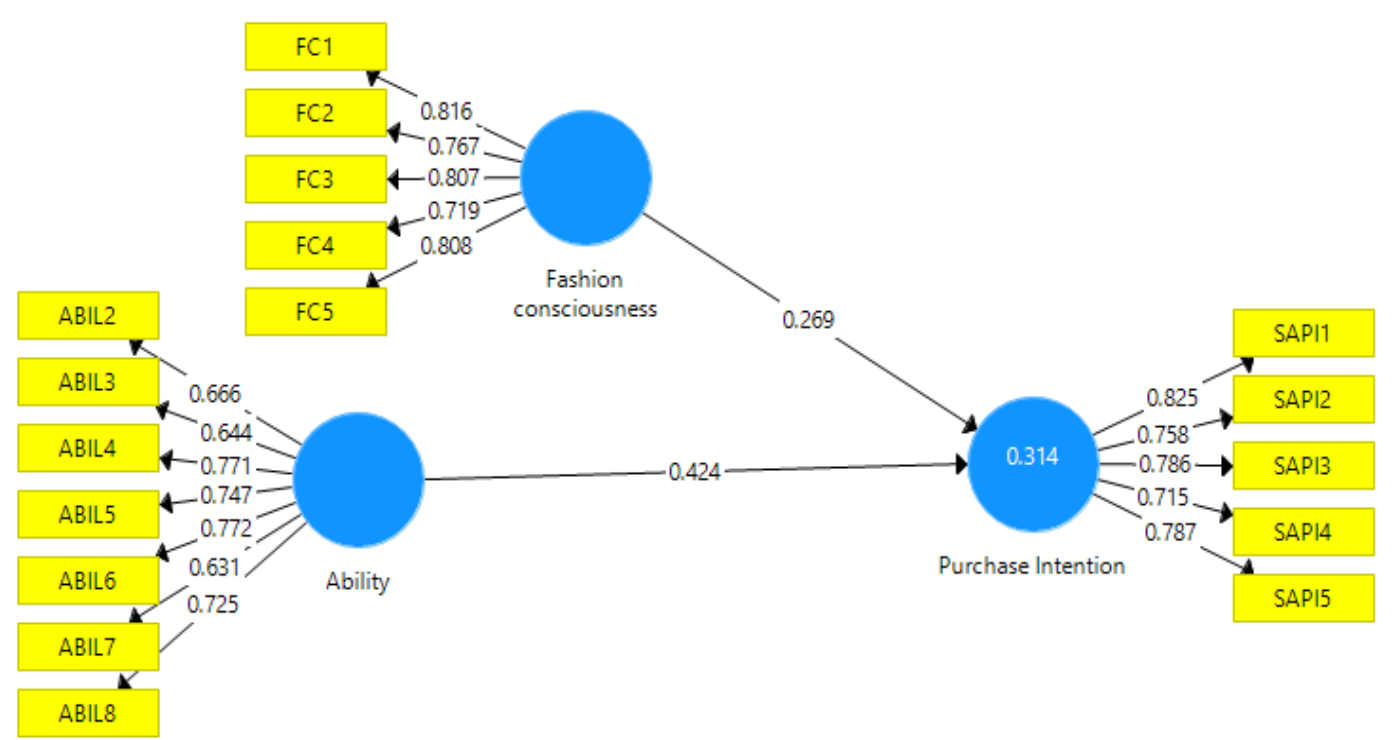

Figure A5. The construct before the inclusion of moderator. 


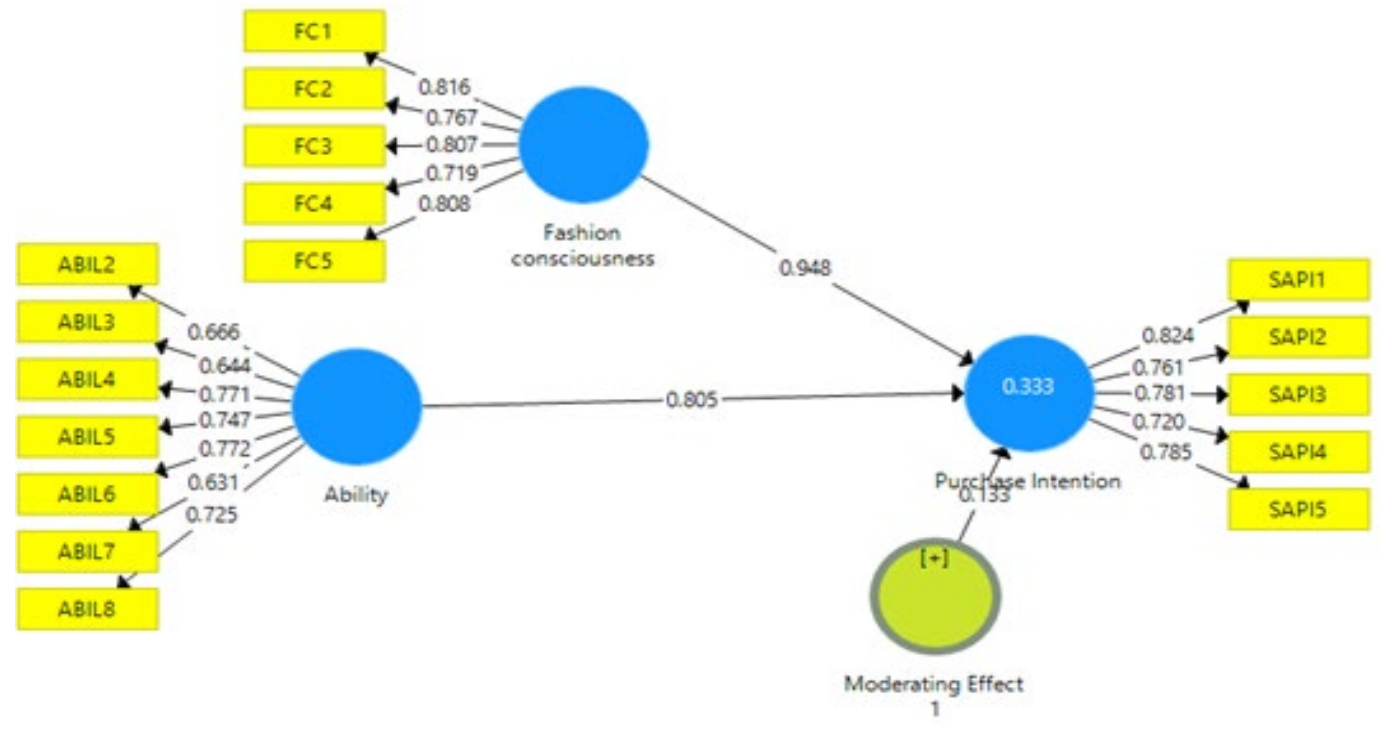

Figure A6. The construct after the inclusion of moderator.

\section{References}

1. Gunther, M. Pressure Mounts on Retailers to Reform Throwaway Clothing Culture. The Guardian. 2016. Available online: https: //www.theguardian.com/environment/2016/aug/10/pressure-mounts-on-retailers-to-reform-throwaway-clothing-culture (accessed on 4 January 2021).

2. Qutab, M. What's the Second Most Polluting Industry? (We'll Give You a Hint-You're Wearing It). One Green Planet. 2017. Available online: https://www.onegreenplanet.org/environment/clothing-industry-second-most-polluting/ (accessed on 22 January 2021).

3. Woodside, A.G.; Fine, M.B. Sustainable fashion themes in luxury brand storytelling: The sustainability fashion research grid. J. Glob. Fash. Mark. 2019, 10, 111-128. [CrossRef]

4. Ahmad, N.; Ullah, Z.; Arshad, M.Z.; Kamran, H.W.; Scholz, M.; Han, H. Relationship between corporate social responsibility at the micro-level and environmental performance: The mediating role of employee pro-environmental behavior and the moderating role of gender. Sustain. Prod. Consum. 2021, 27, 1138-1148. [CrossRef]

5. Amed, I.; Balchandani, A.; Beltrami, M.; Berg, A.; Hedrich, S.; Rölkins, F. The State of Fashion 2019. McKinsey \& Company. 2018. Available online: https://www.mckinsey.com/industries/retail/our-insights/the-state-of-fashion-2019-a-year-of-awakening (accessed on 7 March 2021).

6. Khandual, A.; Pradhan, S. Fashion brands and consumers approach towards sustainable fashion. In Fast Fashion, Fashion Brands and Sustainable Consumption; Muthu, S., Ed.; Textile Science and Clothing Technology; Springer: Singapore, $2019 ;$ pp. 37-54.

7. Murtaza, S.A.; Mahmood, A.; Saleem, S.; Ahmad, N.; Sharif, M.S.; Molnár, E. Proposing stewardship theory as an alternate to explain the relationship between CSR and Employees' pro-environmental behavior. Sustainability 2021, 13, 8558. [CrossRef]

8. Gupta, S.; Nawaz, N.; Alfalah, A.A.; Naveed, R.T.; Muneer, S.; Ahmad, N. The Relationship of CSR Communication on Social Media with Consumer Purchase Intention and Brand Admiration. J. Theor. Appl. Electron. Commer. Res. 2021, 16, 68. [CrossRef]

9. Thorisdottir, T.S.; Johannsdottir, L. Corporate social responsibility influencing sustainability within the fashion industry. A systematic review. Sustainability 2020, 12, 9167. [CrossRef]

10. Janaina, A.K.; Miguel, P.; Davi, B.G.; Barrella, W. Textile sustainability: A Brazilian etiquette issue. Environ. Sci. Policy 2020, 109, 125-130. [CrossRef]

11. Jia, F.; Yin, S.; Chen, L.; Chen, X. The circular economy in the textile and apparel industry: A systematic literature review. J. Clean. Prod. 2020, 259, 120728. [CrossRef]

12. Youn, C.; Jung, H.J. Semantic network analysis to explore the concept of sustainability in the apparel and textile industry. Sustainability 2021, 13, 3813. [CrossRef]

13. Global Fashion Agenda. Bandana Tewari as Special Adviser to the Summit. 2018. Available online: https://www. globalfashionagenda.com/bandana-tewari-of-vogue-india-joins-as-summit-advisor/\# (accessed on 10 January 2021).

14. Bendell, J.; Kleanthous, A. Deeper Luxury-Quality and Style When the World Matters. J. Chem. Inf. Model. 2007, 53, 1689-1699.

15. Souri, A.; Navimipour, N.J.; Rahmani, A.M. Formal verification approaches and standards in the cloud computing: A comprehensive and systematic review. Comput. Stand. Interfaces 2018, 58, 1-22. [CrossRef]

16. Shen, D.; Richards, J.; Liu, F. Consumers' awareness of sustainable fashion. Mark. Manag. J. 2013, 23, $134-147$.

17. Carey, L.; Cervellon, M.C. Ethical fashion dimensions: Pictorial and auditory depictions through three cultural perspectives. $J$. Fash. Mark. Manag. 2014, 18, 483-506. [CrossRef]

18. Henninger, C.E.; Alevizou, P.J.; Oates, C.J. What is sustainable fashion? J. Fash. Mark. Manag. Int. J. 2016, 20, 400-416. [CrossRef] 
19. Hennigs, N.; Wiedmann, K.-P.; Klarmann, C.; Behrens, S. Sustainability as Part of the Luxury Essence: Delivering Value through Social and Environmental Excellence. J. Corp. Citizsh. 2013, 2013, 25-35. [CrossRef]

20. Guercini, S.; Ranfagni, S. Sustainability and Luxury: The Italian Case of a Supply Chain Based on Native Wools. J. Corp. Citizsh. 2014, 2013, 76-89. [CrossRef]

21. Chen, C.C.; Chen, C.W.; Tung, Y.C. Exploring the consumer behavior of intention to purchase green products in belt and road countries: An empirical analysis. Sustainability 2018, 10, 854. [CrossRef]

22. Mei, N.S.; Wai, C.W.; Ahamad, R. Environmental awareness and behaviour index for Malaysia. Procedia-Soc. Behav. Sci. 2016, 222, 668-675. [CrossRef]

23. Malaysia External Trade Development Corporation. Export Prospects for Ethical Fashion Industry. 2017. Available online: https:/ / www.matrade.gov.my/en/archive/3932-export-prospects-for-ethical-fashion-industry (accessed on 31 July 2021).

24. Hasbullah, N.N.; Sulaiman, Z.; Mas'od, A. The Influences of Parasocial Relationship and Sources Credibility in Promoting Sustainable Fashion in Social Network Sites. Int. J. Eng. Adv. Technol. 2020, 9, 1642-1648. [CrossRef]

25. Zhang, D.; Mahmood, A.; Ariza-Montes, A.; Vega-Muñoz, A.; Ahmad, N.; Han, H.; Sial, M.S. Exploring the impact of corporate social responsibility communication through social media on banking customer e-wom and loyalty in times of crisis. Int. J. Environ. Res. Public Health 2021, 18, 4739. [CrossRef]

26. MacInnis, D.J.; Moorman, C.; Jaworski, B.J. Enhancing and measuring consumers' motivation, opportunity, and ability to process brand information from ads. J. Mark. 1991, 55, 32. [CrossRef]

27. Tseng, S.C.; Hung, S.W. A framework identifying the gaps between customers' expectations and their perceptions in green products. J. Clean. Prod. 2013, 59, 174-184. [CrossRef]

28. Ryan, R.M.; Deci, E.L. Self-determination theory and the facilitation of intrinsic motivation, social development, and well-being. Am. Psychol. 2000, 55, 68-78. [CrossRef] [PubMed]

29. Tsai, S. Impact of personal orientation on luxury-brand purchase value: An international investigation. Int. J. Mark. Res. 2005, 47, 427-452. [CrossRef]

30. Truong, Y.; McColl, R. Intrinsic motivations, self-esteem, and luxury goods consumption. J. Retail. Consum. Serv. 2011, 18, 555-561. [CrossRef]

31. Hudders, L.; Pandelaere, M. The Silver Lining of Materialism: The Impact of Luxury Consumption on Subjective Well-Being. J. Happiness Stud. 2012, 13, 411-437. [CrossRef]

32. Nwankwo, S.; Hamelin, N.; Khaled, M. Consumer values, motivation and purchase intention for luxury goods. J. Retail. Consum. Serv. 2014, 21, 735-744. [CrossRef]

33. Ki, C.W.; Kim, Y.K. Sustainable Versus Conspicuous Luxury Fashion Purchase: Applying Self-Determination Theory. Fam. Consum. Sci. Res. J. 2016, 44, 309-323. [CrossRef]

34. Shao, W.; Grace, D.; Ross, M. Consumer motivation and luxury consumption: Testing moderating effects. J. Retail. Consum. Serv. 2019, 46, 33-44. [CrossRef]

35. Razmus, W.; Jaroszyńska, M.; Palęga, M. Personal aspirations and brand engagement in self-concept. Personal. Individ. Differ. 2017, 105, 294-299. [CrossRef]

36. Truong, Y. Personal Aspirations and the Consumption of Luxury Goods. Int. J. Mark. Res. 2010, 52, 655-673. [CrossRef]

37. Eckhardt, G.M.; Belk, R.W.; Wilson, J.A. The rise of inconspicuous consumption. J. Mark. Manag. 2015, 31, 807-826. [CrossRef]

38. Grazzini, L.; Acuti, D.; Aiello, G. Solving the puzzle of sustainable fashion consumption: The role of consumers' implicit attitudes and perceived warmth. J. Clean. Prod. 2021, 287, 125579. [CrossRef]

39. Gazzola, P.; Pavione, E.; Pezzetti, R.; Grechi, D. Trends in the fashion industry. The perception of sustainability and circular economy: A gender/generation quantitative approach. Sustainability 2020, 12, 2809. [CrossRef]

40. Bos, C.; Van Der Lans, I.A.; Van Rijnsoever, F.J.; Van Trijp, H.C.M. Heterogeneity in barriers regarding the motivation, the opportunity and the ability to choose low-calorie snack foods and beverages: Associations with real-life choices. Public Health Nutr. 2016, 19, 1584-1597. [CrossRef]

41. Thøgersen, J. Country differences in sustainable consumption: The case of organic food. J. Macromark. 2010, 30, 171-185. [CrossRef]

42. Wang, P.; Kuah, A.T.H.; Lu, Q.; Wong, C.; Thirumaran, K.; Adegbite, E.; Kendall, W. The impact of value perceptions on purchase intention of sustainable luxury brands in China and the UK. J. Brand Manag. 2021, 28, 325-346. [CrossRef]

43. Kumar, S.; Yadav, R. The impact of shopping motivation on sustainable consumption: A study in the context of green apparel. J. Clean. Prod. 2021, 295, 126239. [CrossRef]

44. Bly, S.; Gwozdz, W.; Reisch, L.A. Exit from the high street: An exploratory study of sustainable fashion consumption pioneers. Int. J. Consum. Stud. 2015, 39, 125-135. [CrossRef]

45. Brandão, A.; da Costa, A.G. Extending the theory of planned behaviour to understand the effects of barriers towards sustainable fashion consumption. Eur. Bus. Rev. 2021, 33, 742-774. [CrossRef]

46. Connell, K.Y.H. Internal and external barriers to eco-conscious apparel acquisition. Int. J. Consum. Stud. 2010, 34, 279-286. [CrossRef]

47. Gadhavi, P.; Sahni, H. Analyzing the "mindfulness" of young Indian consumers in their fashion consumption. J. Glob. Mark. 2020, 33, 417-429. [CrossRef] 
48. Sandra, N.; Alessandro, P. Consumers' preferences, attitudes and willingness to pay for bio-textile in wood fibers. J. Retail. Consum. Serv. 2021, 58, 102304. [CrossRef]

49. Rahman, O.; Koszewska, M. A study of consumer choice between sustainable and non-sustainable apparel cues in Poland. J. Fash Mark. Manag. 2020, 24, 213-234. [CrossRef]

50. Phipps, M.; Ozanne, L.K.; Luchs, M.; Subrahmanyan, S.; Kapitan, S.; Catlin, J.R.; Gau, R.; Naylor, R.W.; Rose, R.L.; Simpson, B.; et al. Understanding the inherent complexity of sustainable consumption: A social cognitive framework. J. Bus. Res. 2013, 66, 1227-1234. [CrossRef]

51. McNeill, L.; Moore, R. Sustainable fashion consumption and the fast fashion conundrum: Fashionable consumers and attitudes to sustainability in clothing choice. Int. J. Consum. Stud. 2015, 39, 212-222. [CrossRef]

52. Paço, A.; Gouveia Rodrigues, R. Environmental activism and consumers' perceived responsibility. Int. J. Consum. Stud. 2016, 40, 466-474. [CrossRef]

53. Bong Ko, S.; Jin, B. Predictors of purchase intention toward green apparel products: A cross-cultural investigation in the USA and China. J. Fash. Mark. Manag. Int. J. 2017, 21, 70-87. [CrossRef]

54. Munerah, S.; Koay, K.Y.; Thambiah, S. Factors influencing non-green consumers' purchase intention: A partial least squares structural equation modelling (PLS-SEM) approach. J. Clean. Prod. 2021, 280, 124192. [CrossRef]

55. Bloch, P.H.; Commuri, S.; Arnold, T.J. Exploring the origins of enduring product involvement. Qual. Mark. Res. 2009, 12, 49-69. [CrossRef]

56. Kaur, H.; Anand, S. Segmenting Generation Y using the Big Five personality traits: Understanding differences in fashion consciousness, status consumption and materialism. Young Consum. 2018, 19, 382-401. [CrossRef]

57. Choi, T.M.; Luo, S. Data quality challenges for sustainable fashion supply chain operations in emerging markets: Roles of blockchain, government sponsors and environment taxes. Transp. Res. Part E Logist. Transp. Rev. 2019, 131, 139-152. [CrossRef]

58. Wang, H.; Liu, H.; Kim, S.J.; Kim, K.H. Sustainable fashion index model and its implication. J. Bus. Res. 2018, 99, 430-437. [CrossRef]

59. Wagner, M.; Schaltegger, S.; Hansen, E.G.; Fichter, K. University-linked programmes for sustainable entrepreneurship and regional development: How and with what impact? Small Bus. Econ. 2021, 56, 1141-1158. [CrossRef]

60. Todeschini, B.V.; Cortimiglia, M.N.; de Medeiros, J.F. Collaboration practices in the fashion industry: Environmentally sustainable innovations in the value chain. Environ. Sci. Policy 2020, 106, 1-11. [CrossRef]

61. Vehmas, K.; Raudaskoski, A.; Heikkilä, P.; Harlin, A.; Mensonen, A. Consumer attitudes and communication in circular fashion J. Fash. Mark. Manag. 2018, 22, 286-300. [CrossRef]

62. Maclnnis, D.J.; Jaworski, B.J. Information processing from advertisements: Toward an integrative framework. J. Mark. 1989, 53, 1-23. [CrossRef]

63. Petty, R.E.; Cacioppo, J.T.; Schumann, D. Central and peripheral routes to advertising effectiveness: The moderating role of involvement. J. Consum. Res. 1983, 10, 135-146. [CrossRef]

64. Higgins, E.T. Beyond pleasure and pain. Am. Psychol. 1997, 52, 1280-1300. [CrossRef]

65. Higgins, E.T. Regulatory focus as a motivational principle. Adv. Exp. Soc. Psychol. 1998, 30, 1-46.

66. Pelletier, L.G.; Tuson, K.M.; Green-Demers, I.; Noels, K.; Beaton, A.M. Why are you doing things for the environment? The motivation toward the environment scale (MTES). J. Appl. Soc. Psychol. 1998, 28, 437-468. [CrossRef]

67. Tanner, C.; Kast, S.W. Promoting sustainable consumption: Determinants of green purchases by Swiss Consumers. Psychol. Mark. 2003, 20, 883-902. [CrossRef]

68. Barbarossa, C.; De Pelsmacker, P. Positive and Negative Antecedents of Purchasing Eco-friendly Products: A Comparison Between Green and Non-green Consumers. J. Bus. Ethics 2016, 134, 229-247. [CrossRef]

69. La Trobe, H.L.; Acott, T.G. A modified nep/dsp environmental attitudes scale. J. Environ. Educ. 2000, 32, 12-20. [CrossRef]

70. Kim, H.; Karpova, E. Consumer attitudes toward fashion counterfeits: Application of the theory of planned behavior. Cloth. Text. Res. J. 2010, 28, 79-94. [CrossRef]

71. Han, T.I.; Stoel, L. The effect of social norms and product knowledge on purchase of organic cotton and fair-trade apparel. J. Glob. Fash. Mark. 2016, 7, 89-102. [CrossRef]

72. Sprotles, G.B.; Kendall, E.L. A Methodology for profiling consumers' decision-making styles. J. Consum. Aff. 1986, 20, 267-279. [CrossRef]

73. Parker, R.S.; Hermans, C.M.; Schaefer, A.D. Fashion consciousness of chinese, japanese and american teenagers. J. Fash. Mark. Manag. 2004, 8, 176-186.

74. Hair, J.; Hollingsworth, C.L.; Randolph, A.B.; Chong, A.Y.L. An updated and expanded assessment of PLS-SEM in information systems research. Ind. Manag. Data Syst. 2017, 117, 442-458. [CrossRef]

75. Bhattacherjee, A. Social Science Research: Principles, Methods, and Practices; Global Text Project. 2012. Available online: https://digitalcommons.usf.edu/oa_textbooks/3/ (accessed on 26 October 2021).

76. Augustine, A.A.; Rindita, A.S.; Muniandy, S.L. Factors Influencing the Purchase Behaviour of Sustainable Fashion among Millennial Consumers in Kuala Lumpur; ACM International Conference Proceeding Series; Association for Computing Machinery: New York, NY, USA, 2019; pp. 330-334.

77. Wijayaningtyas, M.; Nainggolan, T.H. The millennial generation purchase intention toward green residential building. Int. J. Sci. Technol. Res. 2020, 9, 2054-2059. 
78. Parment, A. Generation Y vs. Baby Boomers: Shopping behavior, buyer involvement and implications for retailing. J. Retail. Consum. Serv. 2013, 20, 189-199. [CrossRef]

79. Wang, J.; Wang, S.; Xue, H.; Wang, Y.; Li, J. Green image and consumers' word-of-mouth intention in the green hotel industry: The moderating effect of Millennials. J. Clean. Prod. 2018, 181, 426-436. [CrossRef]

80. Breckenridge, J.; Jones, D. Demystifying Theoretical Sampling in Grounded Theory Research. Grounded Theory Rev. 2009, 8, 112-126.

81. Malaysian Communications and Multimedia Commission. Internet Survey. 2020. Available online: https://www.mcmc.gov.my/ skmmgovmy/media/General/pdf/IUS-2020-Report.pdf (accessed on 24 February 2021).

82. Hair, J.F.; Risher, J.J.; Sarstedt, M.; Ringle, C.M. When to use and how to report the results of PLS-SEM. Eur. Bus. Rev. 2019, 31, 2-24. [CrossRef]

83. Hair, J.F.; Sarstedt, M.; Hopkins, L.; Kuppelwieser, V.G. Partial least squares structural equation modeling (PLS-SEM): An emerging tool in business research. Eur. Bus. Rev. 2014, 26, 106-121. [CrossRef]

84. Hair, J.F., Jr.; Hult, G.T.M.; Ringle, C.M.; Sarstedt, M. A Primer on Partial Least Squares Structural Equation Modeling (PLS-SEM), 2nd ed.; Sage: Thousand Oaks, CA, USA, 2017.

85. Hair, J.F.; Black, W.C.; Babin, B.J.; Anderson, R.E. Multivariate Data Analysis, 7th ed.; Prentice Hall: Upper Saddle River, NJ, USA, 2010.

86. Fornell, C.; Larcker, D.F. Evaluating structural equation models with unobservable variables and measurement error. J. Mark. Res. 1981, 18, 39. [CrossRef]

87. Henseler, J.; Ringle, C.M.; Sarstedt, M. A new criterion for assessing discriminant validity in variance-based structural equation modeling. J. Acad. Mark. Sci. 2014, 43, 115-135. [CrossRef]

88. Voorhees, C.M.; Brady, M.K.; Calantone, R.; Ramirez, E. Discriminant validity testing in marketing: An analysis, causes for concern, and proposed remedies. J. Acad. Mark. Sci. 2016, 44, 119-134. [CrossRef]

89. Ringle, C.M.; Sarstedt, M.; Straub, D.W. A critical look at the use of PLS-SEM in MIS quarterly. MIS Q. 2012, 36, iii-xiv. [CrossRef]

90. Garson, G.D. Partial Least Squares: Regression and Structural Equation Models; Statistical Associates Publishers: Asheboro, NC, USA, 2016.

91. Cohen, J. Set Correlation and Contingency Tables. Appl. Psychol. Meas. 1988, 12, 425-434. [CrossRef]

92. Chin, W.W.; Marcolin, B.L.; Newstead, P.R. A partial least squares latent variable modeling approach for measuring interaction effects: Results from a monte carlo simulation study and an electronic-mail emotion/adoption study. Inf. Syst. Res. 2003, 14, 189-217. [CrossRef]

93. Dawson, J.F. Moderation in management research: What, why, when, and how. J. Bus. Psychol. 2014, 29, 1-9. [CrossRef]

94. Li, D.; Xu, X.; Chen, C.-F.; Menassa, C. Understanding energy-saving behaviors in the American workplace: A unified theory of motivation, opportunity, and ability. Energy Res. Soc. Sci. 2019, 51, 198-209. [CrossRef]

95. Tabatabaei, M.; Aghbashlo, M.; Dehhaghi, M.; Panahi, H.K.S.; Mollahosseini, A.; Hosseini, M.; Soufiyan, M.M. Reactor technologies for biodiesel production and processing: A review. Prog. Energy Combust. Sci. 2019, 74, 239-303. [CrossRef]

96. Mohd Suki, N.; Mohd Suki, N. Consumption values and consumer environmental concern regarding green products. Int. J. Sustain. Dev. World Ecol. 2015, 22, 269-278. [CrossRef]

97. Kumar, B.; Manrai, A.K.; Manrai, L.A. Purchasing behaviour for environmentally sustainable products: A conceptual framework and empirical study. J. Retail. Consum. Serv. 2017, 34, 1-9. [CrossRef]

98. Khare, A. Antecedents to Indian consumers' perception of green apparel benefits. Res. J. Text. Appar. 2020, 24, 1-19. [CrossRef]

99. Yang, S.; Song, Y.; Tong, S. Sustainable retailing in the fashion industry: A systematic literature review. Sustainability 2017, 9, 1266. [CrossRef]

100. Hasbullah, N.N.; Sulaiman, Z.; Mas, A.; Hasbullah, N.N.; Sulaiman, Z.; Mas, A. The effect of perceived value on sustainable fashion consumption in the era of COVID-19: A proposed conceptual framework. Int. J. Acad. Res. Bus. Soc. Sci. 2020, 1, 895-906. [CrossRef]

101. Lai, C.K.M.; Cheng, E.W.L. Green purchase behavior of undergraduate students in Hong Kong. Soc. Sci. J. 2016, 53, 67-76. [CrossRef]

102. Wang, Y.; Wang, J.; Wang, X. COVID-19, supply chain disruption and China's hog market: A dynamic analysis. China Agric. Econ. Rev. 2020, 12, 427-443. [CrossRef]

103. Rustam, A.; Wang, Y.; Zameer, H. Environmental awareness, firm sustainability exposure and green consumption behaviors. J. Clean. Prod. 2020, 268, 122016. [CrossRef]

104. Hofstede, G. Culture and organizations. Int. Stud. Manag. Organ. 1980, 10, 15-41. [CrossRef]

105. DeLaney, J.; Miller, N. In the Shadow of the State: Intellectuals and the Quest for National Identity in Twentieth-Century Spanish America. Lat. Am. Polit. Soc. 2001, 43, 146. [CrossRef]

106. Halder, P.; Hansen, E.N.; Kangas, J.; Laukkanen, T. How national culture and ethics matter in consumers' green consumption values. J. Clean. Prod. 2020, 265, 121754. [CrossRef]

107. Abdullah, A. Going Glocal-Cultural Dimensions in Malaysian Management; Malaysian Institute of Management: Selangor, Malaysia, 1996.

108. Lee, E.J.; Bae, J.; Kim, K.H. The effect of sustainable certification reputation on consumer behavior in the fashion industry: Focusing on the mechanism of congruence. J. Glob. Fash. Mark. 2020, 11, 137-153. [CrossRef] 
109. De Maya, S.R.; López-López, I.; Munuera, J.L. Organic food consumption in Europe: International segmentation based on value system differences. Ecol. Econ. 2011, 70, 1767-1775. [CrossRef]

110. Ritter, Á.M.; Borchardt, M.; Vaccaro, G.L.R.; Pereira, G.M.; Almeida, F. Motivations for promoting the consumption of green products in an emerging country: Exploring attitudes of Brazilian consumers. J. Clean. Prod. 2015, 106, 507-520. [CrossRef]

111. Wai Yee, L.; Hassan, S.H.; Ramayah, T. Sustainability and philanthropic awareness in clothing disposal behavior among young Malaysian consumers. SAGE Open 2016, 6, 1328-1339. [CrossRef]

112. Pérez-Consuegra, N.; Mirabal, L.; Jiménez, L.C. The role of biological control in the sustainability of the Cuban agri-food system. Elem. Sci. Anthr. 2018, 6, 79. [CrossRef]

113. Sekaran, U.; Bougie, R.; Sekaran, U.; Bougie, R. Research Methods for Business: A Skill Building Approach; John Wiley \& Sons: Hoboken, NJ, USA, 2016.

114. Han, H.; Park, A.; Chung, N.; Lee, K.J. A near field communication adoption and its impact on Expo visitors' behavior. Inter-Natl. J. Inf. Manag. 2016, 36, 1328-1339. [CrossRef]

115. Kumar, V. Transformative marketing: The next 20 years. J. Mark. 2018, 82, 1-12. [CrossRef]

116. Beldad, A.; Hegner, S. Determinants of fair trade product purchase intention of Dutch consumers according to the extended theory of planned behaviour. J. Consum. Policy 2018, 41, 191-210. [CrossRef] 